\begin{tabular}{|l|c|c|c|r|}
\hline $\begin{array}{l}\text { Cuadernos de Investigación Geográfica } \\
\text { Geographical Research Letters }\end{array}$ & 2018 & N $^{\circ} 44(1)$ & pp. 137-169 & $\begin{array}{r}\text { ISSN 0211-6820 } \\
\text { eISSN 1697-9540 }\end{array}$ \\
\hline
\end{tabular}

DOI: http://doi.org/10.18172/cig.3380

\title{
INTEMPERATE WEATHER IN VIOLENT TIMES - NARRATIVES FROM THE WESTERN BALKANS DURING THE LITTLE ICE AGE (17-18TH CENTURIES)
}

J. MRGIC

Department of History, Faculty of Philosophy, University of Belgrade, Serbia.

\begin{abstract}
The paper aims to present narrative sources from the late phase of 'Little Ice Age' period for a part of the Southeastern Europe, which is still poorly investigated. In the lack of solid evidence, obtained by geo-sciences (dendrochronology, sediment and pollen analysis, records of instrumental measurements, etc.), the text relies on documentary 'proxies' derived from several chronicles and short notes. These accounts - from Dalmatian cities of Split and Makarska, Ottoman metropolis of Sarajevo, Franciscan monasteries in Krě̌evo (Bosnia) and in Šarengrad (Srem, after Habsburg re-conquest) - are unevenly distributed in time and geographical space, far from the quality of 'weather diaries', which existed elsewhere in Europe of this period. Nonetheless, the preserved sources verify in their own manner cumulative changes occurring throughout the region: people observed changes not only in high frequency of change of seasonal temperature and precipitation patterns and the scale, but more significantly, there was coupling of extreme weather events and heavy disturbances of weather patterns. Franciscan writers in Makarska and Kreševo repeatedly wrote how weather features and course of seasons were untimely, unexpected, sudden and detrimental, 'suis temporibus non correspondens', and how particular agricultural works could not be performed 'ut moris est', at the usual, traditional schedule, due to the weather perturbances. Adriatic summers turned extremely hot and dry, with long periods without any rain, while data from Šarengrad corroborate results obtain in the historical climatology for Hungary on the severity of winters and long period of frozen Danube River. Mulla Basheski's records from Sarajevo yield information on Miljacka River flood events, in connection to both climate condition and land-use patterns. This paper is foremost an attempt to draw attention to research possibilities for the Western Balkans, and there are more documentary, narrative and archival sources to be further investigated, with collaborations among geoscientists and historians.
\end{abstract}


Clima intempestivo en tiempos violentos - Narrativas de los Balkanes Occidentales durante la Pequeña Edad del Hielo (siglos XVII-XVIII)

RESUMEN. Este trabajo trata de presentar las fuentes narrativas de la última fase de la Pequeña Edad del Hielo para una parte del sureste de Europa, que ha sido pobremente estudiada. En ausencia de evidencias sólidas, obtenidas por las geociencias (dendrocronología, análisis sedimentológico y polínico, registros instrumentales, etc.), el texto se basa en "proxies" documentales derivados de diversas crónicas y breves apuntes. Estas fuentes -desde las ciudades dálmatas de Split y Makarska, la metrópolis otomana de Sarajevo, los monasterios franciscanos en Krě̌evo (Bosnia) y en Šarengrad (Srem, después de la reconquista por parte de los Habsburgo) - están desigualmente distribuidas en el tiempo y en el espacio, тиy lejos de la calidad de los 'diarios del tiempo' que existieron en muchos puntos de Europa en ese periodo. No obstante, las fuentes conservadas verifican a su manera los cambios acumulados en la región: la gente observó cambios no sólo en la alta frecuencia de fluctuaciones de la temperatura estacional y los patrones de precipitación, sino que, de manera más significativa, se dio una coincidencia entre eventos extremos y grandes perturbaciones de los patrones del tiempo. Cronistas franciscanos de Makarska y Krě̌evo escribieron repetidamente que los rasgos del tiempo y el curso de las estaciones fueron intempestivos e inesperados, bruscos y perjudiciales, 'suis temporibus non correspondens', y que los trabajos agrícolas no podían llevarse a cabo 'ut moris est', según los esquemas tradicionales, debido a las perturbaciones climáticas. Los veranos en el Adriático se volvieron extremadamente calurosos y secos, con largos periodos sin lluvia, mientras que los datos de Šarengrad corroboran los resultados obtenidos en la climatología histórica de Hungría acerca de la severidad de los inviernos y el largo periodo en que el río Danubio permanecía helado. Los registros del mulla Basheski en Sarajevo proporcionan información sobre los eventos de avenida del río Miljacka, en relación con las condiciones climáticas y los patrones de uso del suelo. Este artículo es principalmente un intento de llamar la atención sobre las posibilidades de investigación en los Balcanes occidentales, dada la existencia de muchas fuentes documentales, narrativas y archivísticas con posibilidades de ser investigadas mediante la colaboración entre geocientíficos e historiadores.

Key words: climate change, Little Ice Age, narrative sources, chronicles, Southeastern Europe, 17-18th centuries.

Palabras clave: cambio climático, Pequeña Edad del Hielo, fuentes narrativas, sureste de Europa, siglos XVII y XVIII.

Received: 24 July 2017

Accepted: 9 September 2017

Corresponding author: Jelena Mrgic, Department of History, Faculty of Philosophy, University of Belgrade, Serbia. E-mail address: jmrgic@f.bg.ac.rs 


\section{Introduction}

During the third week of April 2017, the Western Balkans were hit by a strong cold wave and "unseasonable" heavy snowfall, which made headlines in the region; parts of central and eastern Bosnia, as well as western Serbia, experienced power shortages. While these had significant impacts on the local population, raspberry and strawberry farmers were in a dire situation: the heavy snowfall broke branches and the morning frost damaged the fruit, decreasing the expected production and its associated income. These berries are high-quality crops that are exported to EU countries, and therefore a highly prized agricultural commodity, expanding under the global market rules perhaps outside the limits of sustainable production (Spaić 2017; CBI 2017).

This contemporary example of how one unusual and extreme weather event is perceived, described, and experienced, can be of assistance when analyzing past observations and reactions to similar natural phenomena. Environmental awareness is not an imminent trait of humans, but the result of experience, a prolonged exposure to the ever-changing conditions of the living environment; furthermore, perceptions of changes are shaped according to the expected and average variation. Both the individual and the social memory are important conveyers of past experiences, traditional knowledge, and coping strategies. As opposed to modern 'culture of progress', the preindustrial time this text deals with, that is, agro-ecological production regime, was dominated by a 'culture of survival' (Hassan, 2000, 121-140).

This paper aims to fill the void in the substantial body of literature on past climate research in Europe and the Mediterranean basin, given that this particular area of the Western Balkans is neglected, and even more, to present a range of possibilities in view of the historical sources still not thoroughly investigated. Since this is an individual endeavor, there are necessary limitations in regard to the time span -the 17th and 18th centuries, and the number of presented sources- four major chronicles, with a number of marginal notes from liturgical manuscripts. The authors were not producers but consumers, and are presented here to discuss different geoecological and socio-cultural environments, providing first hand testimonies on weather features and climatic events among other topics (Mrgić, 2016a, 2016b). Considering all, here would be suggested rather preliminary remarks, in difference to results which could be further calibrated into decadal and centennial series, as it is usually performed by teams of experts.

The study area is the Western Balkans, referred to as a sub-region of Southeastern Europe, circumscribed by the chosen sources -the first is the chronicle from the Franciscan monastery in the Adriatic city of Makarska, covering the period between 1712/20 and 1772; the second stems from the Franciscan monastery of Kreševo in Central Bosnia and it is quite short, encompassing less than a decade, i.e. 17651771; the third is the chronicle of a Muslim scribe from nearby Sarajevo, and brings information from 1746 to 1806 , and the fourth is the Franciscan chronicle from the historical province of Srem (Syrmium) in the Pannonian basin, limited for this occasion to the period between 1683 and 1800 . The paper will address geographical and physical features as a background for historical sources, originating in different 
Kulturkreisen - Venetian, Habsburg, and Ottoman, during the preindustrial economy and pre-instrumental period of climatic research.

The term 'Little Ice Age' (LIA henceforth, ca. 1550-ca. 1850) stems from historical climatology, coined to denote the last period when the lower summer insolation of the Northern Hemisphere caused the mountain glaciers in Europe to dramatically advance, which is attributed to two main factors: several extremely strong volcanic eruptions with volcanic veils blocking the sun radiation to earth surface (Robock, 2000; Thordarson et al., 2003; Gao et al., 2008), and the total sun irradiance went through cyclic changes, including three minima activity periods: Spörer minimum (ca. 1460-1550), Maunder minimum (1645-1715), and Dalton minimum (ca. 1790-1820) (Wanner et al., 2008). During the past several decades, LIA has been the subject of countless studies and scientific projects, as one of the most popular topics, so the choice of important works for Europe and this paper is quite difficult, yet necessary to make (Pfister, 1988; Xoplaki et al., 2001; Brazdil et al., 2005; Matthews and Briffa, 2005; Brazdil et al., 2010; Dobrovolny et al., 2010; Hughes, 2014).

The LIA was a global phenomenon, though far from homogenous, both in spatial and temporal features. With observed regional differences within Europe, it was generally a time with cooler and wetter conditions, colder winters, springs and autumns with extremely abundant precipitation, and a general temperature decline per seasons and per annual average. This has affected agricultural production of the most climate-sensitive crops: wheat and grapevines, due to their biological inability to withstand colder and wetter climate regime, leading to extreme harvest failures and poor quality of wine (Le Roy Ladurie, 1971; Le Roy Ladurie, 1980). As the result, farmers in the Swiss and German lands turned to growing more resistant bread grains, such as spelt wheat (Pfister, 2007), while in eastern Habsburg lands, in the territory of today Lower Austria, farmers gave up winegrowing in larger extent, and shifted to beer production (Landsteiner, 1999). These climate-triggered changes are also testified for Ottoman Bosnia in the early phase of LIA, from 1550 to 1650: in the wine making specialized areas, there was a decrease in production from over 50 percent to complete abandonment of vineyards. Furthermore, and certainly not relating to Islamisation process, wheat cultivation was substituted with barley and spelt wheat. Both are more resistant to wetter and colder conditions during the winter period, which confirms indirectly the change of seasonal weather features. Another result of climate crisis during LIA in the Ottoman Balkans was the transition from winegrowing to plum cultivation and from drinking wine to distilling and drinking plum brandy ('šljivovica') (Mrgić, 2011).

The second part in the title - 'the violent times'- has been chosen purposefully, in order to stress the importance of factors other than climate, namely the impact of frequent wars between the Venetian Republic, Habsburg and Ottoman Empire, affecting the lives of the authors of the analyzed historical sources and the population in the study area during the 17th and 18th centuries. However, this 'background' against which the stories of weather calamities are narrated, has to be presented here only in a very constricted form, due to the focus of this edited 
volume. The starting point for history - LIA climate connection in the Western Balkans was the 'Long war' (1593-1606), followed by the Morea war (1684-1699) in the south of the Balkan Peninsula, and the Holy League war (1683-1699), happening in the vast area of Europe, from Vienna to Skopje and to Sarajevo. The next century brought several shorter, though not less detrimental conflicts - 171418, 1736-39, 1787-91, involving territories in the Adriatic hinterland, Ottoman Bosnia and Serbia, with Transdanubian parts as well (Aksan, 2007). Impacts of wars were manifold, starting from forceful army provisions and the requisition of men, food, and animals, adding up to already strained food production, distribution and supply during the LIA period. Brigandage and wartime pillage destroyed some agricultural areas and settlements; transportation and market disturbances impeded regular food distribution, which increased commodity prices and creation of black-market, smuggling, population movements and migration, spread of disease too, as epidemics usually followed troop movements. Besides this external violence, the inner situation deteriorated due to the "violence from within', evidenced in the chronicle from Sarajevo, where local magnates (ayans) and janissary troops raged against Christians and Jews, but also against the Ottoman emperor and his governor, the Bosnian pasha (Koller, 2004). Urban unrests against corruption, and relating Ottoman government inefficiency, high food prices and market manipulation, as well as guerilla attacks on army troops (uskoks and hayduks), produced a 'culture of violence' and, accordingly, as ways of coping with pressure - a variety of 'economies of violence' (Bracewell, 1992; Mayhew, 2008; Esmer, 2014, 163-199).

Chronicles are documentary sources which yield 'proxies' - indirect or direct data on meteorological variables and season patterns, phenological observations, grain and wine harvest dates and quality, and because natural 'proxies' from dendrochronology, palinology, sedimentology etc. are still missing for the Western Balkans, this type of narrative sources provide unique information as will be presented here (Pfister, 1980; Enzi et al., 2013). These data will be compared to geographically and environmentally similar areas as 'check points', having more continuous and homogenous time series from the LIA period, and more importantly, research results are multidisciplinary efforts.

Along with social constructs - 'climate history', 'average' climate, temperature and precipitation, and reconstructions thereof, one has to address human experiences narrated in various forms and not to float in an abstract world. The most direct and the most general influence of climate variability was on the biophysical level - the volume of food production, problems of sufficiency, availability, and scarcity thereof, as observed in the chronicles.

Modern science clearly discerns between correlation and causality in climate changes, food shortages, and famines. This discourse involves two of Weber's 'ideal types' regarding food crises: its availability decline or its entitlement decline (FAD and FED). Food availability decline involves natural causes, such as climate anomalies and extreme events (prolonged rainfall and snow, or the lack thereof, i.e. drought, cold and heat waves, untimely frost), pests (locusts, mice, rats), and natural disasters (floods, 
landslides), while food entitlement decline proves positive or negative relationships between political and social structures involved in the exchange and allotment of food items, including military actions or price regulation decrees and control (Stathakopoulos, 2004, 35-57ff; Slavin, 2016, 433-447).

This kind of differentiation cannot be expected from the people living and experiencing shortages of food during the LIA period. To all of the authors dealt here with, there was a straightforward causality between unusual weather patterns and their outcomes in food production. In other words, while they observed and recorded FADs, every event was actually an FED, as it was the outcome of socio-natural interplays. It is hard to determine what an 'average' harvest was during the LIA, but as Slavin (2016) demonstrated, people were often faced with harvest insufficiency and shortfalls in some crops, though rarely in majority of them, which is why these shortages did not immediately become full-scale famines.

\section{Study area}

The Western Balkans is part of Southeastern Europe, stretching from the Adriatic Sea in the west to the Sava and Danube Rivers in the northeast, and the valleys of Velika and Južna Morava Rivers to the east (Milačić et al., 2014) (Fig. 1). This sub-region is geographically fragmented into several zones according to geophysical and climate features, influencing soil composition and vegetation cover. The eastern Adriatic coastal area is very jagged with hinterland mountain slopes rising to the Mt Dinara (1913 m), a part of the Dinaric Alps mountain chain, unfolding in northwest-southeast direction, which is the most significant relief feature in the Western Balkans (Cvijić, 1893, 1918). This area is marked with Mediterranean climatic conditions and their bi-seasonality: mild and rainy winters, with January temperatures above the freezing point, and dry and hot summers, with low precipitation level. Influence of the Mediterranean climate spreads northwards up the valley of River Neretva to the cities of Mostar and Konjic, but it also impacts the precipitation regime in the mountains south of Sarajevo, where the Rivers Bosna and Miljacka originate (Rubić, 1957; Marković, 1970; Rogić, 1982). Water issue in Adriatic area, and in Herzegovina especially, is enhanced due to the karstic land composition, so the main body of surface water flows underground, leaving the top soil layer dry and deficient of nutrients, thus making it inadequate for substantial agricultural activity (Cvijić, 1893). This induced that the Adriatic coastal cities, and famous Dubrovnik commune was the prime example, had always to rely on elaborate food supply network from the hinterland, the islands, and further, the Mediterranean basin (Mrgić, 2014). Seasonal wind patterns include winter bora - northeasterly stream bringing rain and increasing humidity, and jugo (scirocco), hot and dry stream (Penzar and Penzar, 1998; Pandžić and Likso, 2005). Vegetation cover varies with altitude and soil composition: the coastal forests of evergreen trees (holm oak and Aleppo pine), with characteristic macchia type of shrubland, as the result of millennia long sylvo-pastoral practice; deciduous forests of broadleaf trees (beech and mixed oak forests) take up lower to medium altitudes; high conifer zone consists of mountain forests of spruce and silver fir (Scarascia-Mugnozza et al., 2000). 


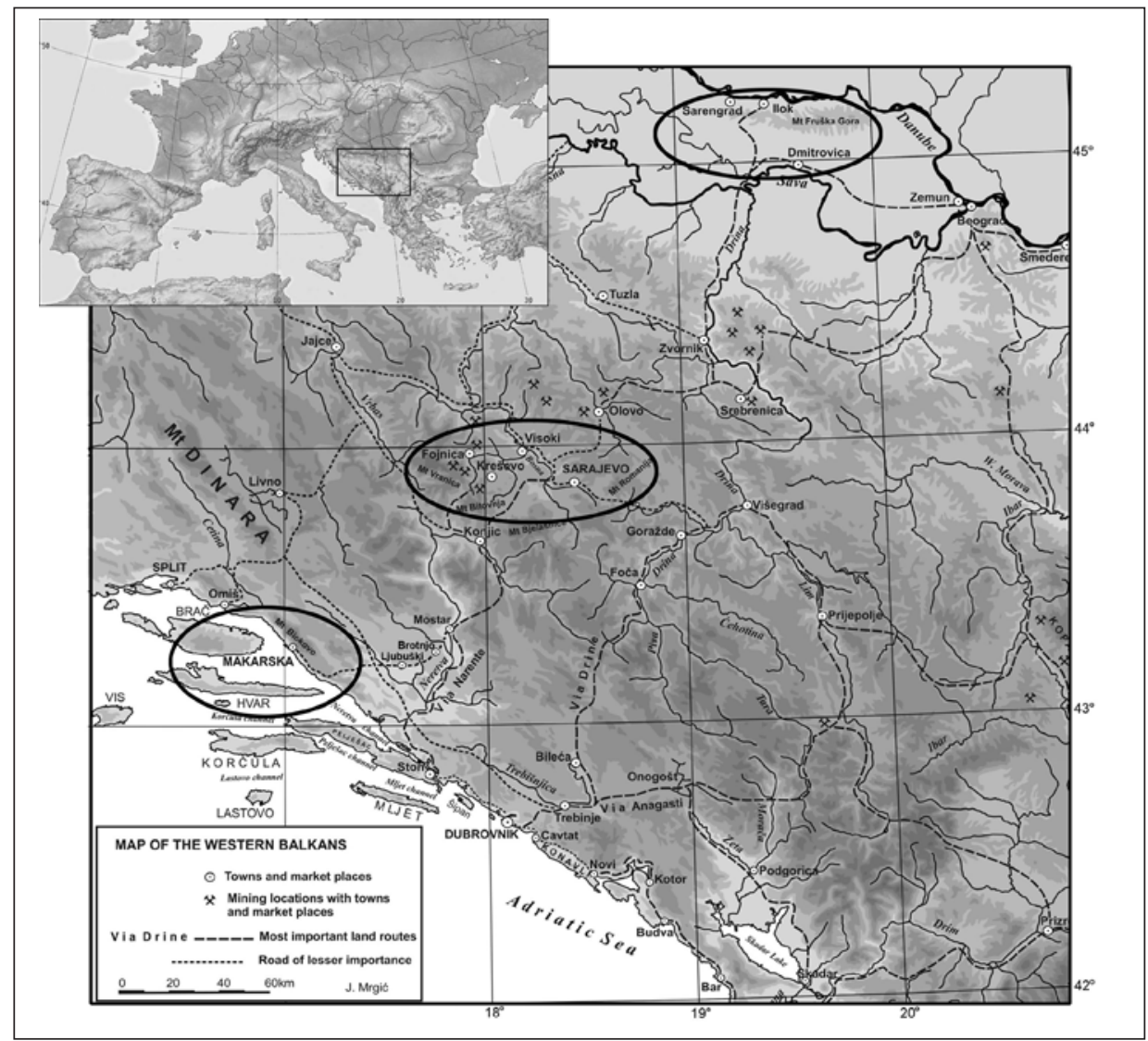

Figure 1. The map of the Western Balkans with relevant toponyms.

The spacious Dinaric Alps mountain chain includes the Central Bosnia area, where two of the chronicles were written, in the cities of Kreševo and Sarajevo. The former is located in the valley of Kreševka stream, a tributary of Fojnička River, flowing to Bosna River in the town of Visoko. Sarajevo was the most important urban center of Ottoman Bosnia, nestled in the valleys of Miljacka and Željeznica Rivers, with numerous streams and creeks. Central Bosnia has limited agricultural capacities, namely, the plains of Visoko and Sarajevo, surrounded by high mountains: Vranica (2110 m), Bitovnja (1700 m), Igman (1504 m), Bjelašnica (2067 m), Treskavica (2086 m), Jahorina (1910), Romanija (1652 m), and Ozren (1534 m). The climate is moderate to continental in the lowlands - cold winters (average January temperature below zero Celsius degrees), and fresh summers (average July temperature below 20 Celsius degrees), while the mountains have alpine climate. Precipitation follows the regular pattern, with two peaks in spring and autumn and abundance of snowfall, and the melting snow significantly influences water levels in the Bosna River basin. Southern wind (jugo, južnjak) can bring warm weather in the winter time, as the chronicle of Kreševo recorded. Medium to high grounds were traditionally used for transhumant pastoralism (Matley, 1968) and woodland exploitation, but the area was also famous for its silver and ferrous mineral deposits 
and mines, as well as mineral baths in Ilidža and Kiseljak since the Roman time. Vegetation cover is much diversified, with many relict species; however, the low laying oak forests had suffered most due to the population pressure. Mixed forests of beech with firs dominate in the medium to high altitude, along with spruce, but are partially deforested and turned into subalpine and alpine meadows in the high-mountain area (Marković, 1970; Rogić, 1982; Sugar, 1963; Stupar and Čarni, 2017).

Historical province of Srem (Sirmium, Syrmium) lies in the southern part of the Pannonian plain, between the Rivers Danube and Sava, divided by the very low mountain of Fruška Gora (539 m), with mild slopes and Paleozoic geomorphologic origin. This area has moderate to continental climate, though with inclination to drier precipitation regime of the steppe climatic conditions, specifically during summer: summers are hot and dry, with mean annual level of only 400 to $600 \mathrm{~mm}$ of rain. Winters are cold and snowy, with famous northerly wind which can reach extreme strength and had halted traffic on the Danube River, same as the formation of ice cover. The letter is evidenced in the Chronicle of the Franciscan monastery of Šarengrad, and will be further used as an indirect climate indicator. Srem used to have much more woodland and spacious wetlands near the river shores as natural retention areas; however, due to extensive work on channelization, drainage and melioration, which started during the Habsburg times (1699-1918), and ensued thereafter, the land use patterns are completely changed in favor of agriculture. The slopes of Fruška Gora were famous as winegrowing areas, particularly the environs of Karlovci (Marković, 1970; Rogić, 1982; Milačić et al., 2014).

\section{Data sources}

Narrative sources are biased (as expected); in this section I aim to present the general tone of their discourse, including their reasons for writing about a particular topic, the audience they were targeting, the way they gathered their information, the character of their data and accuracy thereof. I have selected three chronicles by Franciscan friars, two with known authors and one anonymous, as well as a тестиа, a diary of a Muslim scribe from Sarajevo, Mulla Basheski (1747-1804) (Table 1).

The narratives originated in different cultural environments: Christian (Adriatic-Venetian), Christian (Franciscan - Bosnian), Islamic (Bosnian), and Christian (Franciscan - Habsburg). Leaving the content analysis for some future occasion, I would just point here that the common thread of these stories are their reports on the observed meteorological variables and extreme events, and in that regard, they all perceived untimeliness (intempestivus), sudden alterations, and distortion of weather patterns as signs of a much greater disorder in nature. These aberrations of the usual and expected, elicited great fears of their potential immediate consequences: food availability and the general well-being of people. Extreme weather events, hail, blizzards, and whirlwinds, similar to earthquakes and comets, were memorable and easy to be recorded, so their frequency cannot be an 'objective' measure in narrative sources. Christian chroniclers often, though not methodically, ascribed to Nature's manifestations the usual meaning of divine punishment for sinful humans, as penitence. However, as these texts were not written to be published and widely disseminated, they lack the thunderous voice of preaching. Each author was, underneath it all, as Salman Rushdie poetically noted, "the Storytelling Animal, and that in stories are his identity, his meaning, and his lifeblood" (Rushdie, 2010). 
Table 1. Overview of narrative sources relevant for the LIA in the Western Balkans during the 17th-18th c. (remodelled after: Domínguez-Castro et al., 2016)

\begin{tabular}{|c|c|c|c|c|}
\hline Sources & $\begin{array}{l}\text { Continuity and } \\
\text { relevance for } \\
\text { weather data }\end{array}$ & Time coverage & Space coverage & $\begin{array}{c}\text { Frequency of } \\
\text { entries on weather } \\
\text { data }\end{array}$ \\
\hline $\begin{array}{l}\text { Chronicle of Fra Pavo } \\
\text { Šilobadović }(?-1686)\end{array}$ & $\begin{array}{l}\text { Continuous } \\
\text { Medium } \\
\text { relevance }\end{array}$ & $1662-1686$ & $\begin{array}{l}\text { Makarska and } \\
\text { the frontier area } \\
\text { of Venetian } \\
\text { Dalmatia } \\
\text { and Ottoman } \\
\text { Herzegovina }\end{array}$ & $\begin{array}{l}\text { Monthly, mostly } \\
\text { political events, } \\
\text { except for extreme } \\
\text { weather events }\end{array}$ \\
\hline $\begin{array}{l}\text { Chronicle of Fra Nikola } \\
\text { Gojak }(1680-1772)\end{array}$ & $\begin{array}{l}\text { Most } \\
\text { continuous and } \\
\text { consistent } \\
\text { Most relevant }\end{array}$ & $1712 / 21-1772$ & $\begin{array}{l}\text { Makarska, } \\
\text { Venetian } \\
\text { Dalmatia and } \\
\text { hinterland }\end{array}$ & $\begin{array}{l}\text { Weekly, frequent } \\
\text { daily and, less } \\
\text { frequently, monthly } \\
\text { entries, and } \\
\text { overview of seasons }\end{array}$ \\
\hline $\begin{array}{l}\text { Fra Gojak’s Continuators } \\
\text { 1. Fra Petar Antulović } \\
\text { (1706-1781) } \\
\text { 2. Fra Bartul Ribarović } \\
\text { (1724-1781) } \\
\text { 3. Fra Andrija Ivičević } \\
\text { (1740-1799) }\end{array}$ & $\begin{array}{l}\text { Continuous and } \\
\text { consistent } \\
\text { High relevance }\end{array}$ & $\begin{array}{l}1773-1780 \\
1780-1781 \\
1781-1794\end{array}$ & $\begin{array}{l}\text { Makarska, } \\
\text { Venetian } \\
\text { Dalmatia and } \\
\text { hinterland }\end{array}$ & $\begin{array}{l}\text { Weekly, monthly, } \\
\text { and extreme events } \\
\text { with precise dates }\end{array}$ \\
\hline $\begin{array}{l}\text { Chronicle of fra Marijan } \\
\text { Bogdanović (ca. 1720- } \\
1772 \text { ) }\end{array}$ & $\begin{array}{l}\text { Continuous and } \\
\text { consistent } \\
\text { High relevance }\end{array}$ & $1765-1771$ & $\begin{array}{l}\text { Kreševo in } \\
\text { Central Bosnia, } \\
\text { with entries on } \\
\text { farther away } \\
\text { places }\end{array}$ & $\begin{array}{l}\text { Seasonally, monthly, } \\
\text { and extreme events } \\
\text { with precise dates }\end{array}$ \\
\hline $\begin{array}{l}\text { Diary (mестиа) of Mulla } \\
\text { Basheski (1731/2-1809) }\end{array}$ & $\begin{array}{l}\text { Continuous and } \\
\text { consistent } \\
\text { High relevance }\end{array}$ & 1746-1806 & $\begin{array}{l}\text { Sarajevo and } \\
\text { news from other } \\
\text { parts of the } \\
\text { Ottoman empire }\end{array}$ & $\begin{array}{l}\text { Islamic holidays, } \\
\text { seasonally, and } \\
\text { extreme events with } \\
\text { precise dates }\end{array}$ \\
\hline $\begin{array}{l}\text { Chronicle of the } \\
\text { Franciscan monastery of } \\
\text { Šarengrad }\end{array}$ & $\begin{array}{l}\text { Continuous } \\
\text { and consistent, } \\
\text { depending on } \\
\text { the authors } \\
\text { (anon.) } \\
\text { High relevance }\end{array}$ & $\begin{array}{l}\text { Total coverage: } \\
\text { 1683-1907, } \\
\text { Here used: } 1683- \\
1800\end{array}$ & $\begin{array}{l}\text { Region of } \\
\text { Srem/Sirmium } \\
\text { and Habsburg } \\
\text { Slavonia }\end{array}$ & $\begin{array}{l}\text { Monthly and } \\
\text { seasonally entries, } \\
\text { and extreme events } \\
\text { with precise dates }\end{array}$ \\
\hline $\begin{array}{l}\text { Chronicle of Fra Nikola } \\
\text { Lašvanin (ca. 1703-1750) } \\
\text { from the Franciscan } \\
\text { monastery of Fojnica }\end{array}$ & $\begin{array}{l}\text { Compendium } \\
\text { of various } \\
\text { chronicles } \\
\text { and writings, } \\
\text { discontinuous } \\
\text { Medium } \\
\text { relevance, } \\
\text { except for } \\
\text { extreme events }\end{array}$ & $\begin{array}{l}\text { General } \\
\text { chronicle - from } \\
\text { the Creation to } \\
1690 \text { AD } \\
\text { Bosnian } \\
\text { chronicle - } \\
1682-1750 \\
\text { The Chronicle } \\
\text { of Fojnica } \\
\text { monastery 1300- } \\
1750 \\
\text { etc. }\end{array}$ & $\begin{array}{l}\text { Area of the } \\
\text { Franciscan } \\
\text { Province } \\
\text { of Bosnia } \\
\text { (Bosnia and } \\
\text { Herzegovina, } \\
\text { Slavonia) }\end{array}$ & $\begin{array}{l}\text { Yearly, mostly } \\
\text { political but with } \\
\text { many extreme } \\
\text { weather events data }\end{array}$ \\
\hline $\begin{array}{l}\text { Marginal notes in } \\
\text { Orthodox liturgical } \\
\text { manuscripts }\end{array}$ & $\begin{array}{l}\text { Discontinuous, } \\
\text { mostly } \\
\text { anonymous } \\
\text { High for } \\
\text { specific events }\end{array}$ & $\begin{array}{l}\text { The Middle Ages } \\
\text { and Ottoman } \\
\text { times } \\
\text { 12th to 19th c. }\end{array}$ & $\begin{array}{l}\text { Very dispersed, } \\
\text { various } \\
\text { manuscript } \\
\text { copy centers } \\
\text { in Orthodox } \\
\text { monasteries in } \\
\text { the South East } \\
\text { Europe }\end{array}$ & $\begin{array}{l}\text { Extreme events and } \\
\text { natural disasters }\end{array}$ \\
\hline
\end{tabular}


In geographical order, from the southwest and Adriatic coast to the northeast, and the Danube River, the first text is that of fra Nikola Gojak, who lived in the Franciscan monastery of St Mary in Makarska, writing his chronicles from 1712 to 1772, though his notes became more extensive from the year of 1720 onwards. The city huddled in a narrow strip of coast against Mt Biokovo, which, according to Alberto Fortis, served the inhabitants as a weather indicator, 'il loro Teatro Meteorologico', sending down winds, hail, and rain (Fortis, 1774, 114). Fra Gojak's motivation is clearly stated in the opening page: I wanted to be curious, when something happened, I wanted to write it down, so that it could be found for eternity (Makarski ljetopisi, 1993, 83). His writings are exceptional in view of his sensitivity and multitude of observations, authentic worry and empathy for the well-being of the Christian folk (Mrgić, 2016a). Fra Gojak's climate relating diary entries were usually weekly, even daily observations of weather features, meteorological variables, outcomes of agricultural seasons, success or failure of harvests, and fishing. His writing is thus closest to weather diaries there is for this region of Western Balkans. For example, on May 16, 1750, he wrote: "Inclement weather came from the town of Split in the evening, and during the night, bora started to blow and it snowed heavily way up the hill, to the village, so much as if it were winter, and many animals, small and large, suffered... And the bad and cold weather ensued, and this is what happens when winter is nothing like its nature and ways, but turns to summer and summer turns to winter" (Makarski ljetopisi, 1993, 20). Fra Gojak had three continuators (Table 1) in writing the chronicle of this monastery and the events in the surrounding, just as another friar, Fra Pavo Šilobadović kept records in the previous century. Therefore, Makarska monastery chronicles present unique opportunities for almost bicentennial climate research.

Fra Marijan Bogdanović (ca. 1720-1772), lived and wrote his chronicle in the monastery of Kreševo, ca. 40 km west of Sarajevo, located 640 meters above sea level, surrounded by the high central Bosnian mountains, Bitovnja and Vranica, exposed to sudden bursts of cold weather and winds, as well as southern streams. He was educated in Naples, from around 1740 to 1747, and one may wonder if Aristotle's Meteorologica, Virgil's Georgica and early measurement tools were known to him. Fra Marijan unfortunately developed tuberculosis, which drained energy from his body and made him susceptible to natural phenomena, a type of pre-Zauberberg sensitivity, though he had few small agriculture endeavors in agriculture himself. His chronicle is rather short, it covers the years from 1765 to 1771 , but contains many fine details and personal remarks, similar to fra Gojak's and other Franciscan chronicles in Bosnia. Furthermore, Fra Marijan Bogdanović recorded 'rogationes' (orations, public prayers) on four separate occasions, and these are unique features in the Franciscan chronicles in the Balkans, in contrast to other Roman Catholic societies of that time, where these prayers were common practice and present valuable narrative sources for climate reconstruction (Enzi et al., 2013; Domínguez-Castro, 2016). Though sparse, these records fit the wider context and can be used as climate indicators: the first occasion was on August 2, 1769, when heavy rain incessantly fell for the third week in a row, fra Marijan conducted public prayers for clear skies (ad postulandam serenitatem), so that the grain harvest was successful. The second rogation was pro pluvia (to get the rain) at the end of June, 1770, but not a month after, in the second week of August, fra Marijan had to perform just the opposite! 
This particular year was quite turbulent, while he conducted his last and fourth rogation in the first week of September for the rainfall to stop, and Gottseidank, the autumn grain harvest and thrashing went uninterrupted (Jelenić, 1917, 1-96; Bogdanović, 1984; Mrgić, 2015).

Mulla Basheski's mестиа was a private diary, but in accordance with tradition, the Muslim elite of Sarajevo would gather once a week and read their notes, so he and his companions were quite aware that those words were meant for audience, present and future. This manuscript is thus treated as a chronicle of Sarajevo's social, political, economic and cultural life from 1746 to 1806 . Among the earliest entries in his manuscript one senses his motivation: I am going to record some events in the city of Sarajevo and the eyelet (province) of Bosnia by date, since what is recorded stays, and what is memorized vanishes. Twelve years later, he regretted having made records as soon as he heard news in the çarşi (bazaar), which turned out to be false and premature. He then pledged to be more careful and cautious about writing things down (Filan, 2008, 317346). Basheski had a keen personality, and was inclined to note not only the important events in his city, but as an urban dweller and artisan, he bore witness to consumption patterns, food distribution, market regulation, price politics, as well as regional and general pest epidemics. He also wrote about the coping mechanisms of the Ottoman authorities in times of crises, which were very frequent, due to extensive military actions in the frontier. His records grew in length when he described the quality and quantity of crops, especially fruit, as well as the water volume of the river Miljacka and flooding in the çarşi, and included observations on sky events. He noted the case of late snow destroying the premature blossoms of the fruits in the spring of 1765: "On February 12th, behar appeared on zerdelije. The whole winter was warm and without snow and cold... Just when the behar was in full swing, the snow fell and it became very cold, so much that the behar was frozen. This happened in the month of Shaban (30th March 27th April, 1759)". Behar is a Turkish term for blossoming of the fruits, and zerdelije denote cherry plums, Germ. türkische Kirche, winter cherries, with other Turkish terms dženarike (Prunus cerasifera), or kajsije - apricot (P. armeniaca) (Simonović 1959). Similar to fra Marijan Bogdanović and Catholic public prayers for clear skies (ad postulandam serenitatem), Mulla Bašeski also recorded a case of public prayer (dua) being asked from the Muslims in Sarajevo in the first week of August in 1793, because “the rains were pouring whole year until Alidjun (St Elias' feast, August 2), like it had happened in 1175 [hijra year, 1761/62] before the plague came" (Bašeskija, 1987, 43, 306; Mrgić, 2015; Mrgić, 2016b).

The monastery of Šarengrad was located ten kilometers west of the town of Ilok (Ujlak), on the slopes of Fruška gora in Srem (Sirmium, Syrmium), on the left bank of the Danube (Fig. 2). The Chronicle was composed by different anonymous authors during the long period between 1683 and 1907, and for the purpose of this text, I have used the writing till the end of the 18th century, from the first volume of the printed edition. The style of the authors varied in the amount of information entered, as well as in their inclusion of natural events and calamities suffered by people in the region (Ljetopis Šarengrad, 2002). The location of Šarengrad, at the border between Ottoman Belgrade and Habsburg Zemun and Srem, presents a good check point for climate history, since 
the conditions were similar to those in historical Hungary, moderate and Pannonian, and the Danube River is connected politically and climatically to Central Europe. Historical climatology and paleohydrography studies for medieval and modern Hungary provide solid evidence on climate periods and changes before and after the Ottoman rule, along with observed changes in population survival strategies (Racz, 2010, 21-39; Racz, 2013).

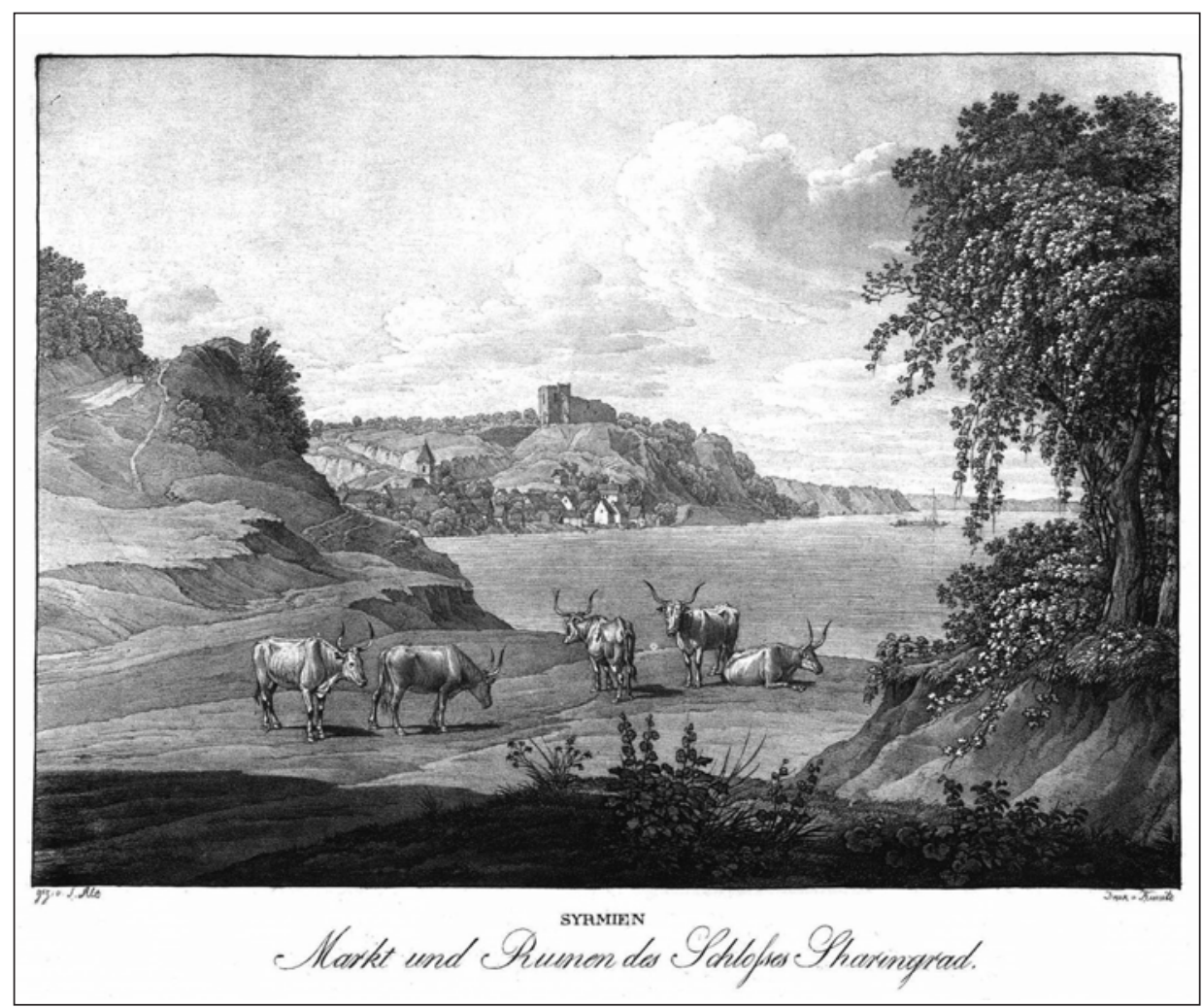

Figure 2. Albert Kunike and Jakob Alt, Syrmien - Markt und Ruinen des Schlosses Sharengrad (1826).

Marginal notes are short records made by mostly anonymous copysts on the margins of liturgical manuscripts in Orthodox Christian monasteries throughout the region of South Eastern Europe. The authors were clergymen and monks, not chronographers, and they left breviloquent records on extreme events and natural disasters: prolonged drought, excessive rainfall, heavy snow, flash floods, locust invasions, famines and plague epidemics. These fragmentary writings are spatially and temporally discontinuous, thus inadequate for making consistent time series, and yet can be used as supplement material (Mrgić, 2011). A six volume collection of Serbian marginal notes and inscriptions has been published before the manuscripts were largely destroyed in the bombardment of the National library of Serbia, on April 6, 1941 (henceforth: Stojanović, SSZiN, first edition 1902-1926, second 1983). Apart 
from Serbian, there are also Bulgarian marginal notes, used to recontruct 'the times of plague' under the Ottoman rule (Manolova-Nikolova, 2004).

The testimonies in this section yield personal observations and indirect (phenological) data on climate variability and its impact on society during the LIA, in different scales of shock, disaster, and prolonged crises. While famines in the Western Balkans were rare, as elsewhere in Europe at that time (Slavin, 2016), there were at least two cases of collective, regional and prolonged food deficiencies in the region, triggered and heavily influenced by a combination of unfavorable climate and impact of war and disease. The first occurred during the Holy League War (1683-1699), when Habsburg, Ottoman, and Venetian military actions caused great devastation and suffering, inducing large population movements from Skopje and Sarajevo to Budapest, and in the opposite direction, following the withdrawal of the Ottoman troops. Violence and insecurity gave almost no opportunity to practice agriculture, hence, the production of food was insufficient and people left their homes -the Great Serbian migration to Habsburg territories north of the Sava and Danube Rivers started in 1690, with a rough estimate of 37,000 families (approximately 185,000 men, women and children) (Popović, 1954). Bosnia was heavily struck by violence: the peak of it was on October 23 and 24, 1697, when Prince Eugene of Savoy burnt the city of Sarajevo to the ground, with many people taken away from Bosnia. What followed was the great famine, testified by historical sources in Ottoman Bosnia and Serbia.

Fra Nikola Lašvanin (ca. 1703-1750), who compiled a chronicle in the Franciscan monastery in Fojnica, near Kreševo, presents an account of alternative food items used during this famine: tree bark, vines, dogs, and cats. Ultimately, he documented cannibalism, which occurred in the şehirs of Sarajevo and Banjaluka (Lašvanin, 1981, 163-164). This extreme behavior was also recorded by an anonymous author in a Sarajevo liturgical manuscript (Stojanović, SSZiN vol. 3, no. 5258).

Though the impacts of war seem to overshadow the LIA climate conditions, within the period of Maunder Minimum of solar activity (1645-1715), there are nevertheless written testimonies which bring evidence on significant climate anomalies enhancing the food deficiency and leading to proper famine: in 1683 a heavy snowfall of 8 palms in height (approx. 2 m: Zupko, 1981), with prolonged cold and frost were recorded in Makarska from January 17 to March 7 (Makarski ljetopisi, 1993, 49, 53) and in the monastery of Mileševa in western Serbia, for 12 consecutive weeks. In 1685, extremely late snowfall was recorded on July 23rd in Mt Biokovo above Makarska, and again on Easter 1696 (April 22nd). "The year of great famine" (1686) was a breviloquent note in several manuscripts in Orthodox monasteries in Serbia and Montenegro. Records also indicate prolonged rainfall during 40 days in 1694 (which, of course, could be just a Biblical reference) (Stojanović, SSZiN, vol. 1, no. 1820, 1856, 1862, 1870, 1872; vol. 3 , no. 5258, 5316, 5710, 5712).

These testimonies also give details of extreme food prices, closing the 'circle': insufficient food led to anarchy and this in turn led to price manipulation. Food items were listed along with their extremely high prices (4 to 5 times higher than before): bread grains (wheat, or mixed wheat), rice, beans, onions, turnip, hay, cheese, wine, and 
brandy. The Ottoman silver coin - akçe (or aspron) was in inflation since the late 1580's and frequent wars only worsened its depreciation (Pamuk, 1995).

The second crisis that I will refer to took place in Dalmatia during 1782-83, and it relates to climate famine triggers, which were aggravated by sanitary cordon imposed to fight a plague outbreak. The cordon completely halted traffic of people and goods, especially food items (grains, cattle, meat), across the borders of the Ottoman Empire, Habsburg, and Venetian lands. An anonymous chronicle from Split Della fame in Dalmazia - Anno 1782 refers directly to this crisis, stipulating the scarcity of grains - wheat, maize, and rice, and, consequently, their extremely high prices in the town market: on average, prices were doubled. The author recorded that in the whole Dalmatia the number of famine victims was 20,000, and in the city of Split - 600 (Prijatelj, 1952).

The same grave situation regarding famine was described in the Franciscan chronicle of Makarska, written by the successor of fra Gojak, fra Andrija Ivičević: the summer of 1781 was very dry and detrimental to grain production, while the autumn was extremely wet and also harmful to grains. Thus, a famine took place between March and May of 1782. The monastery handed out food to at least 380 men weekly. The hope of a new harvest failed due to a prolonged drought from late spring to September of the same year. Grain prices rocketed, following the price of wheat, until January 1783, when the arrival of grain shipments reduced the price to a normal level. It further recorded that in March, April, and May of that year, many poor people died of hunger in villages and in Makarska. What helped the city was the supply from the Adriatic islands and the Ottoman hinterlands, but this soon ended due to the new outbreak of plague from August 1783 to September 1784 (Makarski ljetopisi, 1993, 306-315; Božić-Buzančić, 1996).

Another confirmation of the same regional famine is in Basheski's chronicle: two years before this plague, in 1781 and 1782, there was draught and scarcity of wheat, which was thus sold for three times the 'normal' value (Bašeskija, 1987, 217-219).

\section{Climatic information}

The Mediterranean triad consisted of wheat - with breadbaskets being the Kingdom of Naples, Sicily and Sardinia - grapes, and olives; the sensibility of these crops to oscillations in weather patterns has been used for many decades in historical climatic reconstructions (Le Roy Ladurie, 1971; Le Roy Ladurie et al., 1980; de Vries, 1980; Brazdil et al., 2008). Pre-LIA evidence on the traditional, ecologically-adapted rhythms of agricultural production is preserved in wine harvest (vindemia) calendars in Dalmatian communes, documented in the medieval city statutes which decreed the time for these festivities. In the town of Šibenik, located in northern Dalmatia, the harvest started on September 1st (Old Style calendar until 1582), and lasted the whole month; the town of Split, in the island of Korčula followed a similar calendar that started on August 15th, and in Dubrovnik the beginning of the festivities was August 1st. Thus, the deadline to finish all vineyard work was usually set on June 29th, the day of St Peter's festival; the end of the wine harvest festival was marked by St Michael's day, September 29th 
(Čremošnik, 1933). These dates could be compared to those given in testimonies from Makarska and Šarengrad, as two distant sites on different climate zones.

Data on olive harvest, occurring in late October, are discontinuous in the Makarska chronicle, and can only be used in a lesser extent for climate reconstruction. Prolonged cold and frost, and strong winds damaged the flowers, the buds and the branches, so the olive harvest was quite often decreased with extreme weather events, and this was on several occasions recorded by fra Gojak in his chronicle in Makarska.

The following sections will discuss authors' expressions about irregular weather conditions and perturbed seasons, the climate impacts to crops and the outcomes agricultural year.

\subsection{Winter}

The risks of this season included: premature start of low temperatures and frost; prolonged cold and frost, which lasted a week or two. This caused seeds freezing in the ground, which was tilled very shallow; extreme cold would kill domestic animals kept outside in the open, and insufficiently fed with fodder. Very abundant snow would smother the seeds in the ground, and break the branches of olive trees and vines. The opposite conditions, like the absence of snow cover, and an overall worm winter, would induce premature wakening of grains and fruits, shortening their hibernation period, and making them extremely vulnerable to the mayhems of the spring (Pfister, 1988).

This was already observed and scientifically interpreted by the Italian agrometeorologist, Giuseppe Toaldo (1719-1797), who made an extensive collection of all relevant weather parameters, pointing out to the connection of precipitation, temperature and season pattern regularity as essential for the outcome of the agricultural year and food prices. Toaldo wrote his testimony on this occasion: 'Nel 1765 l'inverno fu tepido, come una primavera, ed ecco per la cagione opposta la scarsezza...' (The winter of 1765 was warm, like a spring, and for that opposite reason, scarcity...). He duly recorded that the alimentation magistrates in Florence observed the fields from the city walls in February, and if they turned green from the offshoots, that would be a sign that the import of grains should be organized henceforth. The experience told them that the late frost or snow would kill the young seedlings, and made the harvest below the sufficient level (Toaldo, 1750). There are, so far, no preserved records of such preventive and foresighted measure in the Dalmatian communes under the Venetian rule, which does not necessarily mean that the traditional knowledge of weather variations and growing conditions was not used by local government.

In his chronicle, fra Nikola Gojak noticed all these disturbances of winter features: prolonged cold, excessive snow cover, and the opposite - warm episodes which induced premature blossoming of the fruits and grains. He expressed his concerns for each disorder, and on several occasions used a traditional proverb: "What January and February don't do, the March will", meaning that when the winter was without snowfall and expected cold, that would happen later and, in his experience, it would bring greater damage to crops and vegetables. This was the case with the winter of 
1758/59 which was a "wonder above all wonders" because it was so unusually warm with clear sky. Fra Gojak showed the greatest sensibility towards wind patterns and their impact on precipitation and temperature: the main wind was bora (northeastern), bringing the snow, while scirocco - southern (jugo) brought rain during winter period (Penzar and Penzar, 1998). His records for February 1760 could serve as an example of his minute attention: on February 2, bora; on 5, bora and snow; on 18, scirocco, on 19, scirocco and rain; on 20, levanter (eastern wind) and rain; on 22, bora and snow; on 26, levanter and snow, on 27, rain and jugo. The 1720s and 1730s winters seemed to be rather dry and warm, the 1740s were overly rainy, or cold and snowy, the winters in 1750s turned mild again, as well as those in the next decade, with rain and jugo. There were exceptional years within this decade, as fra Gojak recorded for March in 1754: he used the comparison to "Viennese years" (i.e. 1683-99), when, as he was told, there were nine huge snowfalls, one above the other, and he wondered whether that year would be even snowier. The cattle died in cold, and there was no milk, meat, or wool. The following year, 1755, the cold in February was such that not only wine but the brandy froze in the barrels! He concluded that such a cold was not witnessed since 1715 , probably relying on a predecessor's notes. Wet and mild winter of 1765 caused the premature offshoots of vines as early as the feast of St Gregory (the 12th of March), but people could not make the pruning due to excessive humidity. His successor, fra Antulović recorded a very harsh winter, with heavy snowfall even down to the seaside in January 1775, and some people were frozen in the blizzard (Makarski ljetopisi, 1993).

Fra Marijan Bogdanović in the monastery of Kreševo elaborated his weather entries, showing his Neapolitan education with opening remarks for the year 1766:

"Annus hic primordiis in suis vicissitudines, fertilitatem, salubritatem, caeteraque humane
conservationi necessaria, et convenientia indicat... Haec siquidem suo tempore visa bonum
annum, suasque vicissitudines portendunt. Neque solum traditioni senior credimus, sed
statim causam ex suis effectibus cognoscimus..." (This year, by its beginning and adequate
change of seasons, indicates good fertility and health, along with other human necessities...
When weather features are in accordance with their time, one expects good and favorable
year. Not only we believe what the elders say, but we observe the cause by its consequence).

This timeliness of season change and its adequate, expected characteristics suis temporibus correspondens (or non correspondens), would be often repeated in his writings, since it ensured the people that the rest of the year would be like that, as expected and usual. Fra Marijan further attributed this cold to be the cure for plague in Bosnia, as was believed by elder people. Quite the opposite was the course of the year 1769 - January and February were so mild, without any snow, and southern winds blew, and he marked them both as 'in suis vicissitudinibus insolitus' and 'intempestivum' extraordinary and intemperate. When late snow and significant cold marked the last days of March, Fra Marijan concluded that it was because the winter was not in accordance with its natural course. (Jelenić, 1917, 19, 43; Bogdanović, 1984, 54, 97-101).

Basheski confirmed, though not precisely, the cold winter of $1765 / 66$, under the hijra year of 1179 [from June 20, 1765 to June 8, 1766]: “This year there was great 
coldness." He also noted that the beginning of the year 1779 was extremely cold, but without much snowfall, and such a dire cold was, according to him, not remembered neither by the oldest nor the wisest men in the city. All public fountains and even cabbage in turşi (Sauerkraut) froze, with many birds dying of cold. Enjoying such weather were kids with their sledges and skates, while others had to fetch fresh water from Miljacka River and from afar (Bašeskija, 1987, 194).

The Chronicle of Šarengrad seems to corroborate the data on cold periods in Central European, i.e. Hungarian climate of the 18th century (Racz, 2013, 179). From 1740 to 1755 winters were very cold and hard, and in the vicinity of Šarengrad, the Danube River was covered in very thick ice sheet, due to the prolonged cold which remained for five months, from November 1740 until the Annunciation holiday on March 25, 1751. It was only then that the ice had broken, and started to float away, but the mass of ice and melted water had severely damaged the watermills. The consequence was that there was no freshly-grounded flour for making bread and the people suffered from hunger (Ljetopis Šarengrad, 2002, 19-20). Additional Hungarian records show that cold and snowy winters prevailed during the last two decades of this century. In this Franciscan monastery, the records on the Danube ice cover were made in the winter of 1784, lasting from January to March, followed by flooding of the River Danube (Ljetopis Šarengrad, 2002, 110-11). This writer, similar to Makarska confratres, observed in September 1794 how the year was extremely poor in wheat, rye and barley, because, in his opinion, the winter was like autumn, with warm days, without snow, while the spring rainfall was very late for grains to grow tall. Hence, prices were very high already at the start of September. The following winter brought a heavy snow cover, uninterrupted from December 10 until January 19, and the consequences were grave: the crops were smothered, suffocated under the heavy coating of frozen snow (Ljetopis Šarengrad, 2002, 142-143).

\subsection{Spring}

Extremely low temperatures, prolonged frost and heavy snow cover, as well as very late snow and frost, occurring even in late April and May would frozen the shots of grains, olives and vines. No lesser damage would be caused by heavy rainfall in the time of spring tilling and sowing, inducing mold in seeds, so that they could not germinate and grow. Opposite conditions were not desirable as well: draught, i.e. the absence of timely rainfall for tilling the fields, and after the snowing, would have an impact to the quantity of grain harvest (Pfister, 1988).

Late snow and frost were recorded by fra Gojak in the following years: 1727 (April 18 and 19), 1731 (March 30th, heavy snow), 1737 (8 and 16 April), 1738 (five snow falls in April, the last one on the 25), 1741 (snow and frost from the 20 of March till the 4 of May), 1743 (four snow falls in April, last on the 6 of May), 1749 (frost and snow in April, the last on the 23), 1750 (throughout April, and extremely late snowfall on May the 16), 1753 (on 6 and 8 of May), 1759 (snow blizzard with bora on March the 25th), 1760 (frost in April killed the grapevines buds), 1762 (on May 31 snowfall and frost damaged all of the grains and fruits), 1764 (very cold April, with snow on 28), 1765 (snowy and cold April), 1767 (cold and frost in late March and April - 'This March was more winter 
than February!'; snowfall on May 4), 1769 (snow with bora on May 2, and 7), 1770 (late April snow on 23 and 25). The notes are laconic, but the writer almost always added the perceived damage from this weather: vines and even brandy were frozen (1744), bees and cattle were killed by the cold, the winter changed its place with summer (1750), food was expansive, sardines (European pilchard) were hard to find for four consecutive years (1748-1751) (Makarski ljetopisi, 1993).

Drought, defined as a period of insufficient precipitation affecting the human and animal lives, and the biological cycle of plants, is not a dramatic event, and it takes more time to observe the process, the absence of rainfall and the consequences thereof. It is a more common feature in the Mediterranean eco-climate region (Domínguez-Castro and García-Herrera, 2016), than in the interior of the Balkans, and there are entries in fra Gojak's diary referring to the prolonged spring drought through several weeks or even months, sufficient to cause grave harvest outcome, as it was the case in 1724, 1728, and 1738 - on the last occasion he recorded the loss of millet, vines and olive harvest, owing to the insufficient rainfall. In May 1752, fra Gojak recorded how there was no sardines catch for the past four years, which testifies to a huge disruption of the Adriatic Sea hydroclimate (Makarski ljetopisi, 88, 90-93, 112-113, 150; Grbec et al., 2015).

Fra Marijan recorded damaged done by very late and heavy snow cover in 1765: "Ver autem ejus circa Festum s. Georgij [April 23, Old Style] tanta copia nivis et frigoris fructus omnes in flore jam faecundissimus totaliter consumpsit, ut medietas sustentationis humanae delata videatur... Mures in agris, et seminatis in tanta copia fuere, ut plaga prope egiptiaca visa sit renovata." [This year in spring, around St George's feast, heavy snowfall and great cold destroyed all the multitude of fruits in blossom, as if half of human subsistence is destroyed... So great was the multitude of mice in the fields and sowed land plots that it looked like the plague of Egypt is revived.] This particular mice plague is corroborated by a marginal note, from a manuscript from Bosnia: "7265/1765 AD (Byzantine Creation era starts with the year 5508/9 BC and is converted to anno domini) - That summer, with God permitting, mice ate the food, kukuruz [maize], oats, hemps, linens, seedlings. And people went out at night with torches and killed whole 12 thousand of mice" (Stojanović, SSZiN 2, 1983, 122). Further, a belated spring sowing occurred in 1770, as Fra Marijan recorded: after a snowy winter, March was extremely wet and southern wind melted the snow, increasing the wetness of the soil, but these features persisted throughout April, with snowfall and cold, so that due to overly abundant precipitation and cold the people started neither plowing the fields nor planting the seeds 'uti communiter soliti', contrary to the traditional labor for this month (Jelenić, 1917, 12-13, 52; Bogdanović, 1984, 52, 116-117).

High and frequent variations in spring precipitation and temperatures are recorded in the Chronicle of Šarengrad, which gives a description of the late snow on May 1, 1782, cold and strong winds in May of 1787 damaged the flowering fruit trees; excessively wet springs in 1792, cold and snowy April in 1796, cold and frost in April, with excessive rain in May and June of 1798, which made him write: "Habuimus itaque tempus frigidum, quod suo tempore non fuit!". Climate indicators are notes he left on the water level of the Danube River: in the spring of 1770 , continuing from the previous autumn, high 
waters flooded the market town, situated downhill from the monastery at the right bank of the River Danube (Fig. 2). For this extreme event, which nobody, not even the oldest, remembered, the author pondered about the causes and presented two public opinions: some people attributed the high rise of Drava and Danube Rivers to snow melting in the mountains of Styria; the writer disregarded it on the ground that "all other rivers in Europe have flooded now" and those rivers did not receive the melted snow from the Styria. Other people, he wrote, speculated that this flooding was heralded by the great comet in 1769 (Mrgić, 2016b). After the prolonged cold during January and February, on March the 5th, 1784, the Danube lost its ice cover and started to rise above the right bank, so it flooded the barrel storage with $3 \mathrm{ft}$ high waters $(91.5 \mathrm{~cm})$. This corroborates data on the flooding occurring upstream in the historic Hungary at that time, and in Šarengrad's chronicle was noted that the Danube's level rose and fell three times until May 10. From spring to autumn of 1785 the Danube overflowed the plain on both banks; in May of 1787 the Danube rose again and flooded the opposite bank, and the author recorded that, as he was informed, Sava River also flooded the whole Confinium (Militärgrenze) in Slavonia with Srem. The opposite, dry and very warm spring was in 1788 , when on May 22 started premature and extremely high temperatures, usual for 'dies caniculares' as the author observed, and this heat was described as 'ingens et insolitus'. The 'dog days' refer to high temperatures during the Sirius rising in July, and in the Balkans, it traditionally relates to days after the St Peter's holiday, on June 29th/July 12th, until St Elias - Alidjun on July 20/August 2. The result of prolonged heat was the shortage of vegetables, fruits and grains, which were scorched and dried (Ljetopis Šarengrad, 2002, 58-60, 110, 112, $116,130,144)$.

Basheski recorded an extreme drought, lasting for six months, from Kasum (St Michael's day, the 26 of October) in 1793, until twelve days after St George's feast (the 23 of April) in 1794. The absence of rainfall affected rice harvest, and consequently the price was tripled (measured per $o k k a-1,28 \mathrm{~kg}$, Inalcik, 1983), while the price of wheat remained constantly high in his book (Bašeskija, 1987, 98, 314).

\subsection{Summer}

It could be a challenging season for the harvest outcome: very hot and dry weather, with absence of rainfall over four or more weeks, would torched the crops, drying them completely, in addition to damaging almost all vegetables in the gardens, unless irrigated properly: radish, cabbage, carrots, melons, watermelons, etc. The LIA conditions were usually the contrary to these, and they included extreme wetness, overly abundant rain and low average temperatures - this lack of warmth and sunshine decreased the quantity of sugar in grapes, making the wine very sour; further, the ripen grain stocks were broken down, flattened by heavy rainfall, and grains would rotten on the ground, hence, the harvest would fail due to untimely and excessive rainfall. The seeds must have been dried properly before taken to storage and to flour mills, otherwise, a range of yeast and mold infections could afflict them, making the seeds useless and harmful both for humans and animals. Some ten or more percent of the harvest loss would be attributed to these unfavorable conditions, as well as mice invasion, if the grains were not safely 
storage (Pfister, 1988). There was an extreme long period of drought recorded by fra Pavo Šilobadović in 1662, lasted in Makarska for whole six months, from July to November (Makarski ljetopisi, 1993, 20). Dry periods were more frequent during summer months, as evidenced by fra Gojak in 1731 (five weeks), 1739 (four weeks), 1740 (July without a drop of rain), 1741 (from end of May till October 18), 1742, 1743 (poor harvest of wheat, but millet and sorghum prosperous), 1745 (from June 18 till August 8), etc. July was also marked with frequent and strong hail storms, uprooting trees from the ground, causing massive land and rock slides from the mountain slopes to the seaside. The author stipulated 'točila' (sipari, vertical shafts) as a form of the erosion in karst lands, and though the process is usually enhanced by overgrazing and deforestation, there is not sufficient evidence from this particular period (Makarski ljetopisi, 1993, 98-130ff; Cvijić, 1893).

Fra Marijan Bogdanović conducted the rogation pro pluvia in June, but another one for the clear sky already in August 1770. (Jelenić, 1917, 44, 52, 54; Bogdanović, $1984,106,120,122)$. For the summer of 1782 Basheski recorded forest fires on the Mt Romanija, and it was such a draught that the maize flour was as expensive as wheat, so the poor people gave up the maize. What they probably turned to were lesser grains - rye, barley, mixed grains and rice, but the significant shortage of food persisted for two more years. Wet summer was in 1786, beneficial to melons, watermelons and cucumbers, and in 1793 - the hay was so scarce and cattle were undernourished (Bašeskija, 1987, 96-99, 210, 246, 304).

Reports from Šarengrad on the Danube seem to corroborate in general the summer weather conditions reconstructed for Hungary (Racz, 2013, 180-181), that is, more frequently were observed anomalies in precipitation than in temperature: excessively wet $(1770,1778,1785,1789)$ or very warm with a lack of precipitation $(1772,1774$, $1779,1783,1788,1797)$ which affected the dates of grape harvests and the quality of wine in autumn. Other crops were also affected: excessive rain diminished the wheat harvest, while it was beneficial for maize and hay, and vegetables, as recorded in 1798. Dry and overly hot regime in summer damaged melons, plums, apples and pears. Another interesting feature are entries about very strong hail storms in June and July, occurring in 1786, 1787, and in 1794 (Ljetopis Šarengrad, 2002, 90-146).

\subsection{Autumn}

The outcome of the second sowing of seeds in autumn predicted the quantity of food in the next year, so it was very important to have the favorable weather, without extremes, such as the prolonged summer drought in time of tilling and sowing, which would make the land thickly crusted, hard to break with the spade, hard to till and to sow. The other mishap would be the overly abundant rainfall in time for tilling and sowing, which, same as in spring time, would induce rotting of the seeds in the ground. Animals were kept outside without shelter, and they burnt more calories to preserve the bodyheat, which affected the production of milk and body-mass, i.e. meat and fat volume. Lower quality food - fresh and dried forage, played an important role in determining how many animals should and could be kept during the winter, and how many should 
be slaughtered in November. Furthermore, it was necessary to procure enough salt and wood for the domestic curing of meat, not so much for the home consumption but for trade, along with hard and mature cheese.

Fra Gojak and his successors were eager to observe the volume of grape harvest and the wine quality. An extreme case of early snow on September 29 and 30, 1733 caused the unpicked grapes to freeze in the vines! Very late grape harvest was in 1740, lasting until the feast of All Saints (November 1). In September of 1745, fra Gojak observed an illness of grapes - "leafroll", adding that it was not just the case in Primorje, but in the whole Italy, Istria and Dalmatia. Extreme draught in autumn of 1744 and 1745 caused the water wells to dry completely, and the water supply was and is a large problem in karstic landscape, such is the region of Dalmatia and Makarska. Heavy rainfall delayed autumn sowing in 1750, followed by early beginning of frost and cold from October, and the wet period continued until March next year. Autumns seemed to become either drier or more humid during the 1750 s, recording long periods without a drop of rain for ten weeks in 1751, in 1752, from October to December, in 1757, from July to September, in 1760 from September to November. The lack of precipitation was mostly noticed in September and October, directly influencing the grape harvest quantity and quality. The wetter regime was noticed in 1755, with early snow and great cold in October, extremely abundant rain in November and December of 1758 and 1759, early start of snowfall in October of $1761,1763,1765$, followed by excessive rain, which also marked both summer and autumn in 1766 (Makarski ljetopisi, 1993).

Fra Marijan gives records on traditional goat, sheep and cattle slaughter before the onset of winter, and this labor was 'ut moris est' performed before the monastery's holiday of St Catherine (November 25). The hides were sold to merchants from Sarajevo, and it was how the friars could collect enough money to provide wine from Brotnjo in lower Neretva River valley, south of Mostar (Fig. 1). The quality of wine varied (sour in 1769 , good in 1768,1771$)$, but in general very expensive, for the monastery annually procured at least 24 loads of 80 okkas (1 load equals ca. $103 \mathrm{~kg}$ ), including the troubles with finding carriers in times of insecurity. Another necessity was wax and candles, and on one occasion, in February 1771, fra Marijan wrote how only a dozen of small candles was collected, because of the high price of wax, due to small production of bees ('quod apes hoc anno defecerunt'). This could point to die-out of bees in the hives, or several possible causes, from not enough food for bees (sugar, pollen) to primitive combs management or disease (Jelenić, 1917, 46, 64, 73; Bogdanović, 1984, 111, 138, 153).

The chronicle of Šarengrad reports on a very late autumn sowing in 1772, after the All Saints feast (November 1st), because the whole autumn was very dry and the land was crusted and hard to break. Opposite weather conditions were in the autumn of 1778, when the rainfall lasted three months from August, and the grape harvest started on September 21, but the wine tested like mud. The same poor quality of wine was in 1779, and in 1786, again due to excessive rains, and in 1787 the grapes were picked in the second week of October (8-13), and were very scarce, as in 1788 and 1792. There are few records that the monastery produced plum brandy in its own distillery and sold it at the market, similar to Bosnian monasteries in that time, and this was a source of income 
for those communities to secure other necessary items (Ljetopis Šarengrad, 2002, 28, 44, 64, 90, 100, 110, 116, 122, 134; Mrgić, 2011).

\subsection{Floods as climate indicators in historical research}

Floods are essential part of any fluvial ecosystem, yet they are attracting more attention of various disciplines (geomorphology, hydrology, engineering, climatology etc.) in regard to the increased risk of turning these natural phenomena into extreme events and hazards to people, environment and infrastructure. For the region of South Eastern Europe, the European Environmental Agency (EEA) has estimated that there is a cumulative effect of global warming process and higher occurrence of heavy storms and floods, instigated by land-use practices and mismanagement (EEA SOER, 2010). Research of historical flood events now plays a significant role in every risk assessment and flood management strategy, especially in regard to climate change. Therefore, the literature dedicated to presenting historical sources of flood events and past climate change is increasingly growing, so that many European countries and large parts of greatest river basins have been investigated, considering also changes in land cover composition and industrial uses (Brazdil et al., 1999; Rohr, 2005; Glaser et al., 2010; Sonnlechner et al., 2013; Vadas, 2013).

To this volume of literature, some information regarding the city of Sarajevo and Miljacka River can be added. Basheski recorded on four occasions the flooding of Miljacka River and its tributaries in downtown Sarajevo: in 1181, though undated, it would be at the very beginning of this hijra year, i.e. after May 30,1767 - a torrent flooded the whole çarşi and bezestan; in 1776, between April 30 and June 24, the River Miljacka broke the dam at Bentbasha (Tur.: main dam) (Fig. 3), and carved out a new river bed, and people gathered to watch that wander in a great awe; on June 3, 1778 extreme flooding of Miljacka River occurred, so much that the high waters submerged the çarşi, which looked like sea. His entries for the hirja year of 1206 (from August 31, 1791 to August 19, 1792) are more numerous but unsystematic, and I shall try to put them in seasonal order. Basheski starts with the remark: "This year, like never before, such a huge amount of timber arrived at Bentbasha", where the rafted timber was pulled out from Miljacka River by tomrukcis (wood traders). He also recorded how charcoal was expensive due to excessive rains, certainly because this hindered the monthly process of burning woods. Then he makes a specific entry: "On the 9 night after Kasum, there were thunders and flashes, rains and southern wind, and the morning after, the torrent swept away all the bridges in the city but one! This happened on November 4, or on 18 Rabi-ul-Awwal 1206 [November 16, 1791]." He then adds: "The dam at Bentbasha is destroyed,... and this Isa-beg's dam was now destroyed, because the torrent waters of Miljacka River were bigger than those in 1190 (1776)." The next entry might indicate the cause of the increased occurrence of flash floods and torrential behavior of Miljacka River: "This year, $6000 \operatorname{logs}$ arrived at Bentbasha, and this has never happened before". This extensive cutting timber woods upstream in the catchment area of the river could significantly influence the volume and velocity of surface runoff of stormwater and soil erosion. 
Basheski also recorded two temporarily built wood bridges across Miljacka, one built by tomrukcis at Bentbasha, while the reconstruction of stone bridges of Careva ćuprija was under way (Bašeskija, 1987, 74, 145, 166, 291, 296-299, 330).

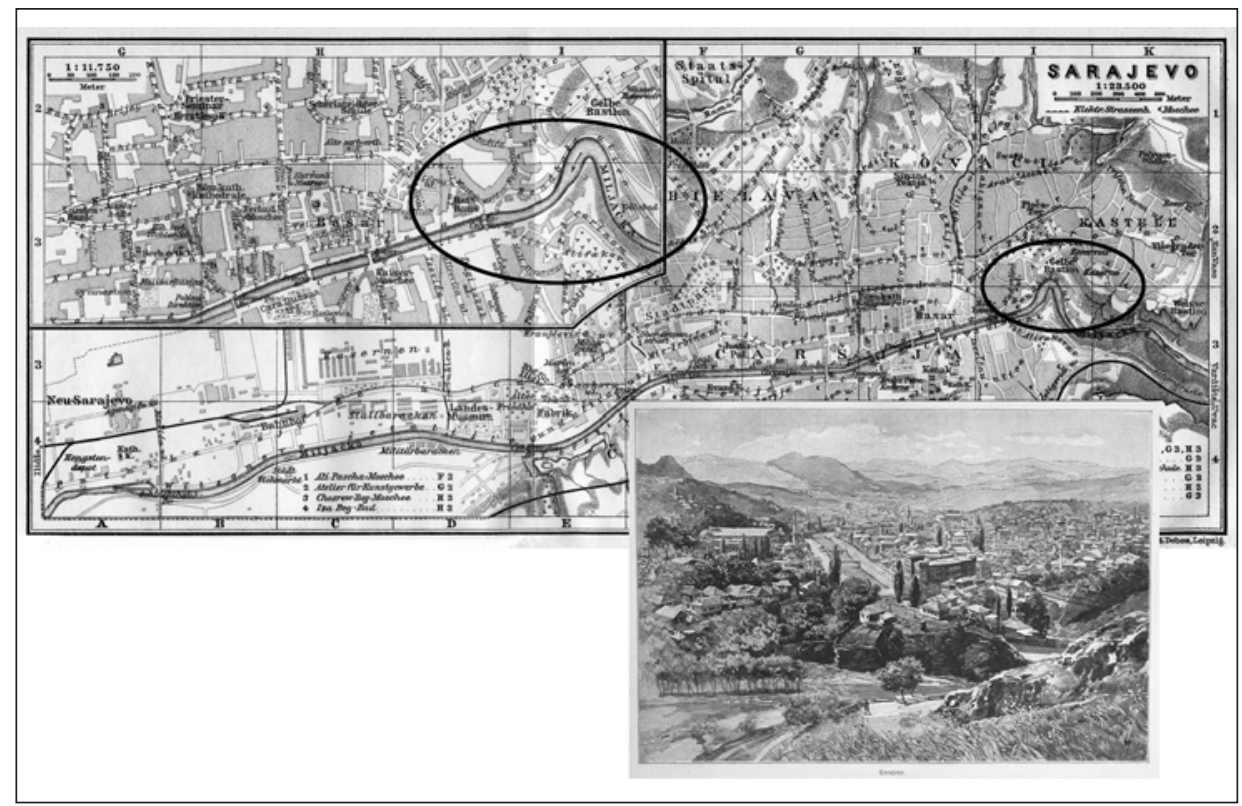

Figure 3. City plan of Sarajevo (1929), with marked Bentbasha, and Julius von Hary's litography of city view (1900), overlooking Bentbasha.

The valley of Sarajevo is surrounded by forested hills and high mountains, drained by a number of streams: Mokranjska and Paljanska Miljacka converge into one river, with smaller rivulets and creeks, such as Mošćanica, Lapišnica and Briješćanski creek. Until the entry at Bentbasha curve, Miljacka River has the character of a mountain river, and this was known to the Ottoman authorities, so that the first, wooden dam (Basheski called it Isa-beg's, i.e. Isa-beg, the founder of şehir Sarajevo, 1443-1470) was built to protect the settlement to the north side, while the water meanders round a protruded rock on the south bank. Further hydrological works ensued, as evidenced in Basheski's chronicle, consisting probably of wooden and tile constructions, until the Austro-Hungarian engineering works from 1884 onwards. The precipitation pattern in the Miljacka River catchment area peaks in spring and autumn, so Basheski's records confirm the periods of excessive rainfall in the Miljacka River basin. Torrential behavior of streams and flash flooding, however, could also be attributed to human impact, namely deforestation process in the karstic hills, due to cutting woods and loggings for large household and manufacture wood and timber consumption of the 18th-century Sarajevo, with 6000 households as Basheski estimated. This could be supported by the huge number of logs rafted and collected at Bentbasha in the year 1791. The debris flow occurred in the summer 
of 1796, when Miljacka River deposited great quantities of rocks, sand and mud in the city center. The people organized a volunteer work to clear the çarşi, and additional ditches were dug out for drainage, and the creek was embanked with tiles. Contemporary analysis shows that lowland urban core of Sarajevo is poorly protected from flooding and a preventive strategy should be applied both in view of urban growth sustainability and water resources management (Bašeskija, 1987, 330; Skarić, 1981, 145-146; Martín-Díaz et al., 2015, 1-10; The Sava River Basin Analysis Report, 2009; Mihajlović et al., 2014).

\section{Discussion}

One of few real famine crises in the Western Balkans was during the period of the Holy League War (1683-1699), and it can be corroborated with evidence during the Maunder Minimum from France and Switzerland, as well as with the price of cereals in Europe. Prices culminated during the period 1688-1694, due to the synergy of unfavourable climate conditions and wars: the first reflected in cold springs and excessively rainy autumns, especially in 1687, 1688, 1689, 1690 and 1692, evidenced in the Chronicle of Makarska and marginal notes (Makarski ljetopisi, 1993, 49, 53; Stojanović, SSZiN, vol. 1, no. 1820, 1856, 1862, 1870, 1872; vol. 3 , no. 5258, 5316, 5710, 5712). In many parts of Europe harvests were noticed to be of insufficient volume (Pfister, 1988). The second famine occurred not only in Dalmatia, where it was well documented, but also in the Ottoman interior, and climatic features were the prolonged summer drought and overly rainy autumn in 1781 , followed by repeated extreme drought during the whole summer and autumn in 1782. The peak of famine in the Adriatic towns of Split and Makarska was in the spring of 1782, from March to May, just before the harvest, but it ensued in lesser extent until the late autumn. The same, extremely dry conditions in 1781 and 1782 were detrimental for grains according to the Sarajevo chronicler Basheski and he also observed how the cereal prices rocketed. Other important factor influencing the availability of food was the plague quarantine, one of the most frequent causes in the Western Balkans.

Plenty of information on high frequency of change of meteorological variables and seasonal patterns can be found in Fra Gojak's chronicle from Makarska (1712/20-1771). His data confirm wetter conditions during winter, which turned more rainy and warmer, while the spring was most critical season in his records, recognized by extremely late frost and snowfalls, from late March, during April and even in May. This was so extraordinary, as if the seasons changed their 'natural' sequence -fra Gojak recorded it on several occasions. The same impressions had fra Marijan and Basheski in Central Bosnia, observing the unusual warmness during winter period, which influenced the premature blossoming of fruits, and then the belated cold during April and May would kill the buds and damaged the harvest. Adriatic summers turned extremely hot and dry, with long periods without any rain, which could last for two months or more. Since the practice of irrigation was limited to gardens only, this resulted in great losses of grains and vegetables, scorched by the heat and drought. Occurrence of summer storms 
with strong winds and hail was quite frequent and furthermore, these storms had great strength to pull out olive trees from the ground and triggered land and rock slides down the mountain slopes. Autumns were of extreme kinds: either wetter and colder, or warmer and drier; in either way these conditions brought great damage to the grain and wine harvests, as well as to olives picking in late October. During the Late Maunder Minimum (LMM 1675-1715) research results for Central Europe and southern Balkans show evidence of colder winters, more severe springs, cooler and wetter summers and autumns in comparison to the whole 20th century reference period (Luterbacher et al., 2001; Xoplaki et al., 2001).

This should be further investigated for Western Balkans and the interior, for example, after the food prices trends, as biophysical climate impact factors, are reconstructed, the way Pfister performed for numerous European towns in this period (Pfister, 2007). The evidence from the Chronicle of Šarengrad during the 18th century seems to be in accordance with weather data reconstruction from Hungarian lands, especially the severity of winters and frozen Danube River (Racz, 2013).

These intemperate, perturbed weather patterns imposed a serious problem to farmers - they had to choose which grains would fit the changed conditions, i.e. they needed winter crops more resistant to wetness, which were barley and rye, and spring crops with shorter growing period than wheat, and hence they turned to millet (Panicum miliaceum, proso) and sorghum (sorgho; Indian millet; sijerak, sirak) in the Adriatic area and hinterland with Mediterranean climate.

Maize (grano turcico, grano indico, furmentun, proha) was also gaining wider use as a buffer crop, but there are still no certain records on the precise growing locations for this period. Maize in Sarajevo reached the prices of wheat in times of scarcity, as Basheski reported. Millet and buckwheat (hajdina, heljda) had been cultivated widely in the Ottoman and Habsburg Slavonia and Srem, along with maize (Adamček, 1980). Spread of rice (Oryza sativa) in the Balkans is attributed to both the wetter climate regime during LIA, and to its extensive use in the Ottoman cuisine (Sharma, 2010). Spacious latifundia-çiftliks - were organized in the valleys of the rivers Marica, Vardar, Nišava, Velika, Zapadna Morava, and Neretva, with their tributaries, and tracing the advance of the Ottoman Empire, into Transdanubian provinces, the Banat of Timişoar. This labor-intensive and high-yield crop was produced not only for the imperial kitchens, as it was also an essential part of imarets (public kitchens). The eco-agricultural demands of growing rice had an undesirable public health consequence: the spread of malaria into irrigated lands. Thus, many fields were abandoned, and only a few were revived in the 19th century, as was the case of Ljubuški in Herzegovina (Tabak, 2008; Singer, 2005).

Another issue to consider might be the volcanic forcing of climate conditions in the Western Balkans during the late LIA, as this has been investigated for other parts of Europe and the world climate in general, based on the ice core layers analyses and total mass of emitted aerosols (Goa et al., 2008). The great Vesuvius eruption on December 16th, 1631, was evidenced only in three short marginal notes, reporting the fallen ashes like the black snow, and without any records on changing 
the weather features in the following months (Mrgić, 2007). Next eruption of the Vesuvius occurred on May 20th, 1737, when the top the mountain exploded, and the whole event was described in great detail by natural scientists. Fra Gojak in Makarska chronicle recorded the following: "Since April 25, there was not a drop of rain, but the scirocco or levante started to blow for days, and it brought heavy darkness all over and everywhere, and on 21st and 22nd this month black ashes fell from the air (skies) as dark as tar, and the wind arose without any rain". Not making any connection between this event and the weather in the following months, he recorded that the grape harvest was rather small in quantity, and the autumn was extremely rainy, in continuo from St Michael's feast (October 8th) to Christmas, and the winter of $1737 / 38$ was 'vicious', with strong bora, heavy rains and snows 'like in the Viennese years' (cf. the entry on the 8 palms tall snow cover in 1683 earlier in this paper) (Makarski ljetopisi, 1993, 110-112; Mrgić, 2016b). These conditions seem to be in correlation to general features of the LIA period, and especially to cooling effect of this particular Vesuvius' eruption.

The infamous Laki eruption, which emitted great quantities of sulphate into the atmosphere, lasting from 8 June 1783 to 7 February 1784, during the whole 8 months, presented a global phenomenon, and was observed in the monastery of Makarska. The successor of fra Gojak, fra Andria Ivičević wrote down his observations: a strange 'darkness' lasted from 20 June till 23 July in 1783, and the Sun was totally invisible, i.e. covered by this darkness which, he added, was not harmful. His further entries provide meagre weather information about that summer and the following autumn and winter (Makarski ljetopisi, 1993, 311), in contrast to research results for Europe (Thoradson et al., 2003). By June 26, the whole Europe was covered by haze, because the volcanic sulphate emission made a huge cloud all over Northern and Western, reaching as far as the Eastern Europe, and making impacts to the weather conditions. Namely, the July temperatures were record high, while the winter 1783-84 was the coldest in decades in Europe and North America. In Hungary, in the summer of 1784, one of the Danube branches had dried up in the town of Pozsony (Bratislava, Slovakia) (Racz, 2013). The phenomenon of "dry fog", "sun smoke" and "haze" was recorded in Sweden, Denmark and German lands, to which now this "darkness" from the Adriatic region can be added. The chronicle from Šarengrad recorded that the Danube River was under the ice cover from January 4 until February 15, 1784, which could support the evidence on extremely cold period of freezing temperatures, lasting for at least six weeks. It was also noticed that in the March of 1784, the Danube overflowed the market below the monastery, and the water level rose and fell three times until May, but without the reference on the extent of flooding, as opposed to records from May 1787 (Ljetopis Šarengrad, 2002, 110, 116). In contrast to the firm slopes of Fruška gora Mt, the opposite bank of the River Danube present vast lowland floodplains as natural retention areas for river stream and rainwater, and are still periodically flooded (Fig. 4). Due to natural features and lack of other historical sources, it is hard to mark this particular reference from 1784 to be fully supportive to the Danube upstream records (Brazdil et al., 2010). 


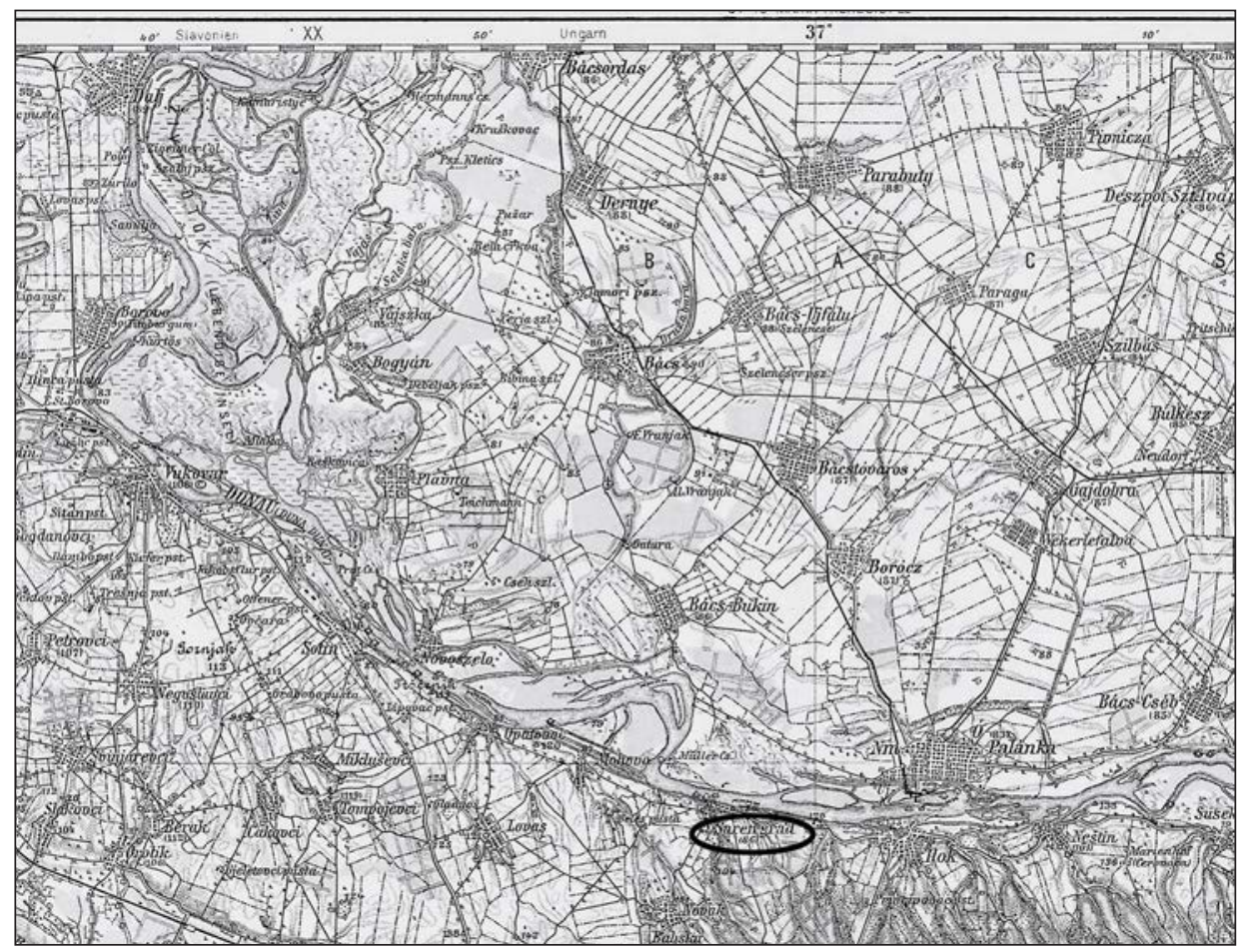

Figure 4. Section of the Austro-Hungarian map (1896) - the position of the Franciscan monastery of Šarengrad with the vast floodplains of the River Danube on the opposite side.

\section{Conclusions}

Four major and dozens of small voices in this chorus sang the songs of turbulent weather, sudden changes of seasons and their irregular features. The suddenness of changes was always perceived as a disorder of Nature, and evoked worries for the human and animal well-being and existence. While real famines -large scale and prolonged food deficiency with mortality-, were relatively rare, testimonies provide evidence not only of alternative food sources, but of the ultimate taboo disrespect survival cannibalism evidenced in 1690, in the Ottoman Bosnia. The chroniclers drew a straight line between the intemperate weather, climate impacts on food production and food shortage, including the interruption of supply routes caused by army movements and quarantine blockades.

The Western Balkans, within the broader context of the Eastern Mediterranean and Southeastern Europe, was in a position between 'hammer and anvil', between the ecological and the LIA global crisis, 'peppered' with social and political instability, wide movements of migrating people, frequent war raids and brigandage, urban unrests, human and animal epidemics. These universal traits of the preindustrial time place this small region as a piece of larger puzzle and the whole picture is yet to be fully completed. 
This paper is an attempt to draw attention to research possibilities for the Western Balkans, and there are more documentary, narrative and archival sources to be further investigated, with collaborations among geoscientists and historians. Therefore, here are presented only preliminary remarks, more descriptive in their character and not calibrated climatological data, and I leave this task to the experts. Another gap has to be filled with research - demographic and economic history against the background of climate changes, in the way how, for example, Guido Alfani performed for Italy (Alfani, 2010; Alfani et al., 2015). Lastly, amidst the heated debate on the measure of human impact on climate change and global warming processes, it is of utmost importance to understand and learn the lessons of history - the past is the present rethinking the pastas Robin Collingwood masterly summarized (Collingwood, 1946). This should allow us to understand other ways of facing and coping with the results of the interplay of nature and society, not limiting these to the Anthropocene period (Crutzen et al., 2003; AriasMaldonado, 2015; Kelly, 2015).

\section{Acknowledgements}

This paper is the result of the work on the project financed by the Ministry of Education, Science and Technological Development of the Republic of Serbia (no. 177010). The work could not commence had it not been the kindness of Assist. Prof. Mario Katić (Faculty of Philosophy, Zadar), who provided the edition of Chronicle of Makarska for me, and Fra Ilija Alandjuk, dean of the Church of St Antun in Belgrade (Province of Bosnian Franciscans), finding for me the Chronicle of Šarengrad, and I am very grateful for their friendship and support. I wish to express my gratitude to Dr Marc Oliva and Prof. García-Ruiz, for collegial help and encouragement during the writing process, and after receiving the first and the second version. The greatest improvements of the text were achieved after two anonymous reviewers expertly commented and corrected the paper in record short time, all for which I am much obliged.

\section{References}

Adamček, J. 1980. Agrarni odnosi u Hrvatskoj od sredine XV do kraja XVII stoljeća [Agrarian relations in Croatia from the middle of the 15th to the end of the 17th c.], Zagreb, $835 \mathrm{pp}$.

Aksan, V.H. 2007. Ottoman Wars 1700-1870: An Empire Besieged. Routledge, Taylor \& Francis Publishing Group, London and New York, 650 pp.

Alfani, G. 2010. Climate, population and famine in Northern Italy: General tendencies and Malthusian crisis, ca. 1450-1800. Annales de Démographie Historique 120 (2), p. 23-53. http://doi.org/10.3917/adh.120.0023.

Alfani, G., Mocarelli L., Strangio, D. 2015. Italian famines: An overview (ca. 1250-1810). Dondena Working Papers 84, 1-31.

Arias-Maldonado, M. 2016. The Anthropocenic turn: Theorizing sustainability in a postnatural age. Sustainability 8-10, 1-17. http://doi.org/10.3390/su8010010.

Bašeskija, Mula Mustafa Ševki. 1987. Ljetopis. transl. and comm. Mehmed Mujezinović. Sarajevo, 2nd edition, $472 \mathrm{pp}$.

Bogdanović, Fra Marijan. 1984. Ljetopis kreševskog samostana (1765-1771). Transl. and comm. by Fra Ignacije Gavran, Sarajevo, 334 pp. 
Božić-Buzančić, D. 1996. Glad, prosjaci, epidemije, higijenske i zdravstvene prilike u Dalmaciji krajem 18. i početkom 19. stoljeća [Famine, Paupers, Epidemics, Hygienic and Health Conditions in Dalmatia at the end of the 18th and Beginning of the 19th Century]. Rad HAZU 29, 138-162.

Bracewell, C.W. 1992. The uskoks of Senj: Piracy, banditry and Holy War in the sixteenth-century Adriatic. Cornell University Press, 352 pp.

Brazdil, R., Glaser, R., Pfister, Ch., Dobrovolny, P., Antoine, J-M., Barriendos, M., Camuffo, D., Deutsch, M., Enzi, S., Guidoboni, E., Kotyza, O., Sánchez Rodrigo, F. 1999. Flood events of selected European rivers in the sixteenth century. Climatic Change 43, 239-285.

Brázdil, R., Wanner H., von Storch, H., Luterbacher, J. 2005. Historical climatology in Europe - The state of the art. Climatic Change 70 (3), 363-430. http://doi.org/10.1007/s10584-0055924-1

Brázdil, R., Zahradniček, P., Dobrovolny, P., Kotyza, O., Valašek, H. 2008. Historical and recent viticulture as a source of climatological knowledge in the Czech Republic. Geografie Sbornik Česke geograficke společnosti 113 (4), 351-371.

Brazdil, R., Demarée, G., Deutsch, M., Garnier, E., Kiss, A., Luterbacher, J., Macdonald, N., Rohr, C., Dobrovolny, P., Kolar, P., Chroma, K. 2010. European floods during the winter 1783/1784: scenarios of an extreme event during the 'Little Ice Age'. Theoretical and Applied Climatology 100 (1-2), 163-189. http://doi.org/10.1007/s00704-009-0170-5.

Brazdil R., Dobrovolny, P., Luterbacher, J., Moberg, A., Pfister, C., Wheeler, D., Zorita, E. 2010. European climate of the past 500 years: new challenges for historical climatology. Climatic Change 101, 7-40. http://doi.org/10.1007/s10584-009-9783-z.

CBI (Centre for the Promotion of Imports from developing countries) - https://www.cbi.eu/ market-information/processed-fruit-vegetables-edible-nuts/frozen-berries/europe/\# (last access: May 22, 2017).

Collingwood, R.G. The Idea of History. Clarendon Press, Oxford, 339 pp.

Crutzen, P.J., Steffen, W. 2003. How long have we been in the Anthropocene Era? Climatic Change $61(3), 251-527$.

Cvijić, J. 1893. Das Karstphänomen. Versuch einer morphologischen Monographie. Geographiche Abhandlungen 5 (3), 218-329.

Cvijić, J. 1918. La Peninsule balkanique. Géographie humaine. Paris, 530 pp.

Čremošnik, G. 1933. Vinogradarstvo i vino u Dalmaciji srednjeg veka, Glasnik Zemaljskog muzeja 45, 1-38.

De Vries, J. 1980. Measuring the impact of climate on History: The search for appropriate methodologies Journal of Interdisciplinary History 10 (4), 599-630.

Dobrovolny P., Moberg, A., Brazdil, R., Pfister, C., Glaser, R., Wilson, R., van Engelen, A., Limanowka, D., Kiss, A., Haličkova, M., Mackova, J., Riemann, D., Luterbacher, J., Böhm, R. 2010. Monthly, seasonal and annual temperature reconstructions for Central Europe derived from documentary evidence and instrumental records since AD 1500. Climatic Change 101, 69-107. http://doi.org/0.1007/s10584-009-9724-x.

Domínguez-Castro, F., García-Herrera, R. 2016. Documentary sources to investigate multidecadal variability of droughts. Cuadernos de Investigación Geográfica 42 (1), 13-27. http://doi. org/10.18172/cig.2936.

EEA SOER 2010. Climate change, in: European Environmental Agency. The European environment - State and outlook report. https://www.eea.europa.eu/soer/synthesis/synthesis/chapter2. xhtml (last access: August 29, 2017).

Enzi, S., Sghedoni, M., Bertolin, C. 2013. Temperature reconstruction for North-Eastern Italy over the Last Millennium: Analysis of documentary sources from the historical perspective. The Medieval History Journal 16 (1), 89-120. http://doi.org/10.1177/097194581301600104. 
Esmer, T.U. 2014. Economies of violence, Banditry and governance in the Ottoman Empire around 1800. Past and Present 224, 163-199. http://doi.org/10.1093/pastj/gtu013.

Filan, K. 2008. Life in Sarajevo in the 18th century - According to Mulla Mustafa's mecmua. In: V. Constantini, M. Koller (Eds.), Living in the Ottoman Ecumenical Community - Essays in Honour of Suriaya Faroqhi. Brill/Leiden - Boston, pp. 317-346.

Fortis, A. 1774. Viaggio in Dalmazia, vol. II, Venezia, 204 pp.

Glaser, R., Riemann, D., Schönbein, J., Barriendos, M., Brazdil, R., Bertolin, C., Camuffo, D., Deutsch, M., Dobrovolny, P., van Engelen A., Enzi, S., Halichova, M., Koenig, S., Kotyza, O., Limanowka, D., Mackova, J., Sghedoni, M. 2010. The variability of European floods since AD 1500. Climatic Change 101 (1-2), 235-256.

Goa, C., Robock, A., Ammann, C. 2008, Volcanic forcing of climate over the past 1500 years: An improved ice core based index for climate models. Journal of Geophysical Research 113. http://doi.org/10.1029/2008JD010239.

Grbec, B., Morović, M., Matić, F., Ninčević, Ž., Marasović, I. Vidjak, O., Bojanić, N., Čikeš-Keč, V., Zorica, B., Kušpilić, G., Matić-Skoko, S. 2015. Climate regime shifts and multi-decadal variability of the Adriatic Sea pelagic ecosystem. Acta Adriatica 56 (1), 47-66.

Hassan, F. 2000. Environmental perception and human responses in history and prehistory. In: R.J. McIntosh, J.A. Tainter, S.K. McIntosh (Eds.), The way the wind blows: climate, history and human action. Columbia University Press, pp. 121-140.

Hughes, P.D. 2014. Little Ice Age glaciers in the Mediterranean mountains. Méditerranée 122. http://mediterranee.revues.org/7146 (last access: May 20, 2017)

Inalcik, H. 1983. Introduction to Ottoman Metrology. Turcica 15, 311-348.

Jelenić, J. 1917. Ljetopis franjevačkog samostana u Kreševu. Glasnik Zemaljskog Muzeja 29, 1-98.

Kelly, J.M. 2015. The Anthropocene: A reading list. http://www.jasonmkelly.com/2015/12/26/theanthropocene-a-reading-list/ (last access: June 25, 2017).

Koller, M. 2004. Bosnien an der Schwelle der Neuzeit - Eine Kulturgeschichte der Gewalt (17471798). R. Oldenbourg Verlag, München, 233 pp.

Kunike, A., Jakob A. 1826. Syrmien - Markt und Ruinen des Schlosses Sharengrad. In: Zwey hundert vier und sechzig Donau Ansichten nach dem Laufe des Donaustromes von seinem Ursprünge bis zu seinem Ausflusse in das schwarze Meer, Wien 1826, source: Digital collection of National Library of Serbia, Danube prospects in old graphics, http://digitalna. nb.rs/wb/NBS/Gravire_i_likovni_materijali/Dunavski_motivi_na_starim_grafikama/GR0297?search_query=Kunike\#page/0/mode/1up (last access: June 10, 2017)

Landsteiner, E. 1999. The crises of wine production in late sixteenth-century Central Europe: Climatic causes and economic consequences. Climatic Change 43, 323-334.

Lašvanin, Fra Nikola. 1981. Ljetopis. Transl. and comm. Fra Ignacije Gavran, Sarajevo, 306 pp.

Le Roy Ladurie, E. 1971. Times of feast, times of famine: A history of climate since the year 1000, New York, 426 pp. (English translation of original: E. Le Roy Ladurie, Histoire du climat depuis l'an mil, Flamarion, Paris, 1967).

Le Roy Ladurie, E., Baulant, M. 1980. Grape harvests from the fifteenth through the nineteenth centuries. Journal of Interdisciplinary History 10 (4), 839-849.

Ljetopis franjevačkog samostana u Šarengradu (Protocollum conventus Franciscani Sarengradini), vol. 1 (1683-1853), prev. dr Josip Barbarić, ur. P. Budimir Cvitković, Šarengrad 2002; vol. 2 (1853-1907), Šarengrad 2006.

Luterbacher, J., Rickli, R., Xoplaki, E., Tinguely, C., Beck, C., Pfister, C., Wanner, H. 2001. The Late Maunder Minimum (1675-1715) - A key period for studying decadal scale climatic change in Europe. Climatic Change 49, 441-462.

Makarski ljetopisi 17. i 18. stoljeća. Ed. Josip A. Soldo, Split 1993. 
Manolova-Nikolova, N. 2004. Čumavite vremena (1700-1850) [The Times of Plague 1700-1850]. Sofia, 315 pp.

Marković, S. 1970. Geografske oblasti SFR Jugoslavije [Geographic regions of SFR of Yugoslavia], Beograd, 869 pp.

Martín-Díaz, J., Nofre, J. Oliva, M., Palma, P. 2015. Towards an unsustainable urban development in post-war Sarajevo. Area 47 (4), 376-385. http://doi.org/10.1111/area.12175.

Matthews, J.A., Briffa, K.R. 2005. The "Little Ice Age": Re-evaluation of an evolving concept. Geografiska Annaler 87, Series A 87, 17-36.

Mayhew, T. 2008. Dalmatia between Ottoman and Venetian Rule - Contado di Zara 1645-1718. Viella, $301 \mathrm{pp}$.

Mihailović, D.T., Nikolić-Đorić, E., Drešković, N., Mimić, G. 2014. Complexity analysis of the turbulent environmental fluid flow time series, Physica A 395, 96-104.

Milačić, R., Ščančar, J., Paunović, M. (Eds.) 2014. The Sava River. The Handbook of Environmental Chemistry vol. 31, Springer Verlag, 506 pp.

Mrgić, J. 2007. "Let it be known when ashes fell from the sky" - The eruption of Vesuvius 1631 $\mathrm{AD}$ and the Balkan lands. Etudes Balcaniques 3, 107-113.

Mrgić, J. 2011. Wine or rak1 - The Interplay of climate and society in the Early Modern Ottoman Bosnia. Environment \& History 17 (4), 613-637.

Mrgić, J. 2014. Rocks, Waters, and Bushes - What did the Ragusan commune acquire from the Bosnian king Stephan Ostoja in 1399? An Environmental History Approach. In: P. Štih, Ž. Zwitter (Eds.), Man, Nature and Environment Between the Northern Adriatic and the Eastern Alps in Premodern Times. Ljubljana, pp. 102-124.

Mrgić, J. 2015. A Polyphony of stories from 17th and 18th-century Southeastern Europe, Godišnjak za društvenu istoriju, 22 (2), 7-24. http://www.udi.rs/articles/j_mrgic_2015_2.pdf (last access: June 6, 2017)

Mrgić, J. 2016a. Osećanja i osećajnost prema prirodi u franjevačkim hronikama (Emotions and sensibility towards nature in the franciscans chronicles). In: T. Brković (Ed.), Bosanski ban Tvrtko „pod Prozorom u Rami “. Ed. Prozor, Sarajevo-Zagreb, pp. 799-812.

Mrgić, J. 2016b. Skyscapes and sky events - Geography of Uncertainties in the Balkans (17th18th centuries). Godišnjak za društvenu istoriju 23 (2), 7-29. http://www.udi.rs/articles/j_ mrgic_2016.pdf (last access: June 6, 2017)

Österreich-Ungarn Landkarte, Blatt : S. Mitrowitz (37-45, the center of the sheet is $45^{\circ}$ North, $37^{\circ}$ East, i.e. east of Ferro, not Greenwich!), 1:200.000, Wien 1910 - Department of Cartography and Geoinformatics - Eötvös Loránd University: Budapest, Hungary, http://lazarus .elte.hu/ hun/digkonyv/topo/200e/37-45.jpg; https://upload.wikimedia.org/wikipedia/commons/4/44/ Mistrowitz_-_37-45.jpg (last access: August 30,2017).

Pamuk, S. 1995. Money in the Ottoman Empire 1326-1914, In: H. Inalcik, D. Quataert (Eds.), An economic and social history of the Ottoman Empire 1300-1914. Cambridge, Cambridge University Press, pp. 947-980.

Pandžić, K.,Likso, T. 2005. Eastern Adriatic typical wind field patterns and large-scale atmospheric conditions. International Journal of Climatology 25, 81-98. http://doi.org/10.1002/joc.1085.

Penzar, I., Penzar, B. 1997. Weather and climate notes on the Adriatic up to the middle of the 19th century. Geofizika 14, 47-82.

Pfister, C. 1980. The Little Ice Age: Thermal and wetness indices for Central Europe. Journal of Interdisciplinary History 10 (4), 665-696.

Pfister, C. 1988. Fluctuations climatiques et prix céréaliers en Europe du XVIe au XXe siècle. Annales Économies, Sociétés, Civilisations 43 (1), 25-53. http://doi.org/10.3406/ ahess.1988.283474. 
Pfister, C. 2007. Little Ice Age-type impacts and the mitigation of social vulnerability to climate in the Swiss canton of Bern prior to 1800. In: R. Constanza, R., L.J. Graumlich, W. Steffen, (Eds.), Sustainability or collapse? An integrated history and the future of people on Earth. Massachusetts Institute of Technology Press and Freie Universität Berlin, pp. 197-212.

Popović, D.J. 1954. Velika seoba Srba 1690 : Srbi seljaci i plemići. Beograd, 348 pp.

Prijatelj, K. 1952. Ljetopis nepoznatog Splićanina od g. 1756. do 1811, "Memoria delle cose successe in Spalato e in Dalmazia, in più villagi, in Bossina e Franzia e in più stati ecc. 1756". Starine JAZU 44, 63-93.

Racz, L. 2010. The price of survival: Transformations in environmental conditions and subsistence systems in Hungary in the age of Ottoman occupation, Hungarian Studies 1, 21-39.

Racz, L. 2013. The steppe to Europe: An environmental history of Hungary in the traditional age. The White Horse Press, 257 pp.

Robock, A. 2000. Volcanic eruptions and climate. Reviews of Geophysics 38, 191-219. http://doi. org/10.1029/1998RG000054.

Rogić, V. 1982. Regionalna geografija Jugoslavije 1 - Prirodna osnova i historijske geografija. [Regional geography of Yugoslavia 1 - Natural features and historical geography]. Zagreb, 219 pp.

Rohr, Ch. 2005. The Danube floods and their human response and perception (14th to 17th). History of Meteorology 2, 71-86.

Rohr, C. 2014. Coping with natural hazards in the Southeast Alpine region in the Middle Ages and in Early Modern times. In: P. Štih, Ž. Zwitter (Eds.), Man, nature and environment between the Northern Adriatic and the Eastern Alps in premodern times. Ljubljana, pp. 290-313.

Rubić, I. 1957. Međe Mediterana na istočnom Jadranu, Geografski pregled 1, Sarajevo, pp. 136148.

Rushdie, S. 2010. Luka and the Fire of Life. Random House, London, 240 pp.

Scarascia-Mugnozza, G., Oslwald H., Piussic, P., Radoglou, K. 2000. Forests of the Mediterranean region: gaps in knowledge and research needs. Forest Ecology and Management 132, 97109.

Sharma, S.D. (Ed.) 2010. Rice: Origin, antiquity and history. CRC Press, Taylor and Francis Group.

Simonović, D. 1959. Botanički rečnik naučnih i narodnih imena biljaka, (Botanical Dictionary of Scientific and Popular Plant Names), Beograd, 890 pp.

Singer, A. 2005. Serving up Charity: The Ottoman Public Kitchen. Journal of Interdisciplinary History 35 (3), 481-500.

Skarić, V. 1985. Sarajevo i njegova okolina od najstarijih vremena do austrougarske okupacije [Sarajevo and its' environs from the earliest times until Austrohungarian occupation]. Sabrana djela 1, ed. Milorad Ekmečić, Sarajevo, 386 pp.

Slavin, P. 2016. Climate and famines: a historical reassessment. WIREs Climatic Change 7, 433447. http://doi.org/10.1002/wwc.395.

Sonnlechner, C., Hohensinner S., Haidvogl, G. 2013. Floods, fights and a fluid river: the Viennese Danube in the 16th century. Water History 5 (2), 173-194. http://doi.org/10.1007/s12685013-0077-z.

Spaić, I. April 19, 2017, Unseasonal snowfall brings Bosnian capital to halt,- http://www. balkaninsight.com/en/article/april-blizzard-surprises-sarajevo-04-19-2017 (last access: May 22, 2017).

Stadtplan von Sarajevo, Geogr. Ang. von Wagner \& Debes, Leipzig (1929), Original scale 1:23,500. Image size (in mm): 98x237, Sarajevo centre map inset: 1:11,750 - Discussmedia. com, the project, “The 1900 Map Collection” - https://www.discusmedia.com/maps/old_ maps_of_sarajevo/4393/ (last access: August 30, 2017). 
Stathakopoulos, D. 2004. Famine and pestilence in the Late Roman and Early Byzantine Empire - A systematic survey of Subsistence Crises and Epidemics. Birmingham Byzantine and Ottoman Monographs vol. 9, Ashgate, 417 pp.

Stojanović, SSZiN - Stojanović, Ljubomir, Stari srpski zapisi i natpisi (Old Serbian notes and inscriptions), vol.1-6, Belgrade 1902-1926, here used 1983, 2nd edition.

Stupar, V., Čarni, A. 2017. Ecological, floristic and functional analysis of zonal forest vegetation in Bosnia and Herzegovina. Acta Botanica Croatica 76 (1), 15-26. http://doi.org/10.1515/ botcro-2016-0041.

Sugar, P. 1963. Industrialization of Bosnia-Herzegovina, 1878-1918. Seattle, 275 pp.

Tabak, F. 2008. The waning of the Mediterranean, 1550-1870: A geohistorical approach. The Johns Hopkins University Press, Baltimore, 308 pp.

The Sava River Basin Analysis Report, International Sava River Basin Commission, Zagreb 2009, http:// www.savacommission.org/dms/docs/dokumenti/documents_publications/publications/ other_publications/sava_river_basin_analysis_report_high_res.pdf (last access: June 10, 2017)

Thordarson, T., Self, S. 2003. Atmospheric and environmental effects of the 1783-1784 Laki eruption: A review and reassessment. Journal of Geophysical Research 108, AAC 7-1-AAC 7-29. http://doi.org/10.1029/2001JD002042.

Toaldo, Guiseppe, Della vera influenza degli astri, delle stagioni, e mutazioni di tempo, Saggio Meteorologico, Padova 1750.

Vadas, A. 2013. The "waters leave their beds frequently": a Western-Hungarian town and the flooding of the Ra'ba/Raab River in the seventeenth century (1600-1658). Water History 5 (3), 267-286. http://doi.org/10.1007/s12685-013-0087-x.

Von Hary, J., ca. 1900. Stadtansicht von Sarajevo. Public domain. https://commons.wikimedia.org/ wiki/File:Sarajevo_Historic_View.jpg (last access: August 30,2017).

Wanner, H., Beer, J., Bütikofer, J., Crowley, T.J., Cubasch, U., Flückiger, J., Goosse, H., Grosjean, M., Joos, F., Kaplan, J.O., Küttel, M., Müller, S.A., Prentice, I.C., Solomina, O., Stocker, T.F., Tarasov, P., Wagner, M., Widmann, M. 2008. Mid- to late Holocene climate change: an overview. Quaternary Science Reviews 27, 1791-1828. http://doi.org/10.1016/j. quascirev.2008.06.013.

White, S. 2011. The Climate of the rebellion in the early Ottoman Empire. Cambridge University Press, Cambridge, 352 pp.

White, S. 2012. The Little Ice Age crisis of the Ottoman Empire: A conjuncture in Middle East environmental history. In: A. Mikhail (Ed.), Water on Sand: Environmental histories of the Middle East and North Africa. Oxford University Press, pp. 71-90.

Xoplaki, E., Maheras, P., Luterbacher, J. 2001. Variability of climate in Meridional Balkans during the periods 1675-1715 and 1780-1830 and its impact on Human Life. Climatic Change 48, 581-615.

Zupko, E.R. 1981. Italian weights and measures from the Middle Ages to the nineteenth century. American Philosophical Society, Philadelphia, 339 pp. 